Florida State University College of Law

Scholarship Repository

Scholarly Publications

2012

\title{
The Irrelevance of Politics for Arbitrary and Capricious Review
}

Mark Seidenfeld

Follow this and additional works at: https://ir.law.fsu.edu/articles

Part of the Administrative Law Commons

\section{Recommended Citation}

Mark Seidenfeld, The Irrelevance of Politics for Arbitrary and Capricious Review, 90 WASH. U. L. REV. 141 (2012),

Available at: https://ir.law.fsu.edu/articles/27

This Article is brought to you for free and open access by Scholarship Repository. It has been accepted for inclusion in Scholarly Publications by an authorized administrator of Scholarship Repository. For more information, please contact efarrell@law.fsu.edu. 


\section{Washington University Law Review}

Volume $90 \mid$ Issue 1

2012

\section{The Irrelevance of Politics for Arbitrary and Capricious Review}

Mark Seidenfeld

Follow this and additional works at: http://openscholarship.wustl.edu/law_lawreview

Part of the Administrative Law Commons, Judges Commons, and the Politics Commons

\section{Recommended Citation}

Mark Seidenfeld, The Irrelevance of Politics for Arbitrary and Capricious Review, 90 WASH. U. L. Rev. 141 (2012).

Available at: http://openscholarship.wustl.edu/law_lawreview/vol90/iss1/3

This Article is brought to you for free and open access by Washington University Open Scholarship. It has been accepted for inclusion in Washington

University Law Review by an authorized administrator of Washington University Open Scholarship. For more information, please contact

arouner@wustl.edu. 


\title{
THE IRRELEVANCE OF POLITICS FOR ARBITRARY AND CAPRICIOUS REVIEW
}

\author{
MARK SEIDENFELD*
}

\begin{abstract}
This Article contends that, properly understood, judicial review of agency action under the reasoned decision-making standard precludes a court from considering political influence, but nonetheless allows an agency to consider it. It does so by identifying two fundamental attributes of such review, as courts have traditionally applied it, that have eluded scholarly focus and perhaps recognition altogether. The first attribute is that agency reasons, which are what courts review, are justifications rather than motivations for agency action. From this attribute, it follows that the irrelevance of politics for judicial review does not preclude politics as a legitimate agency consideration. The second attribute is that reasoned decision-making requires an agency to make manifest the tradeoffs generated by its action. This attribute facilitates political accountability by reducing barriers to public awareness of these tradeoffs. This Article argues that permitting an agency to credit politics as a justification for a rule would interfere with political accountability by relieving the agency of its obligation to reveal the full implications of its rulemaking. Thus, this Article promises to profoundly affect conceptions of the reasoned decision-making standard of review in general and how politics fits within it.
\end{abstract}

\section{INTRODUCTION}

What role should political influence - that is agency consideration of its belief about the preferences of the president or Congress-play in judicial review of agency action ${ }^{1}$ Over the past two decades, several scholars have explicitly called for courts to consider legitimate political influence on agency decision-making as a basis for affirming agency rules

* Patricia A. Dore Professor of Administrative Law, The Florida State University College of Law. Thanks to Lisa Bressman, Curtis Bridgeman, Seth Davis, Linda Jellum, Ron Levin, Emily Meazell, Jerry Mashaw, Jonathan Nash, Glen Staszewski, Peter Strauss, and Fernando Téson for helpful comments on earlier drafts of this Article. Thanks also to Hastings Read and Elizabeth Dehaan for exceptional research assistance.

1. I use the term "political influence" and "consideration of politics" interchangeably to mean agency consideration of such preferences. 
under arbitrary and capricious review. ${ }^{2}$ In 1990, Christopher Edley raised the subject in his book on judicial control of bureaucracy. ${ }^{3}$ Edley criticized the distinction between politics, science, and fairness in agency decisionmaking and suggested that, at least at the margins, the inability to draw lines between these influences on agency action counsels that courts should acknowledge and condone political influence when subjecting such action to hard-look review. ${ }^{4}$ In 2001, Elena Kagan suggested that the president had asserted significant control over rules promulgated by agencies, and that such control imbues rules with legitimacy because of the political accountability of the president. ${ }^{5}$ Kagan also suggested that this increased accountability warrants courts crediting political influence when they engage in review of rules. ${ }^{6}$ Most recently, Kathryn Watts has renewed the suggestion that courts allow agencies to invoke political influence to bolster their justification of rules upon hard-look review. ${ }^{7}$

In calling for consideration of politics in judicial review, these scholars all rely on a perception that hard-look review is antagonistic to agency consideration of politics. As Edley phrased it, "[t]he dominant theme of case law ... is clearly that hard-look review provides a means of cabining

2. When the Administrative Procedure Act (APA) was enacted, its arbitrary and capricious basis for reversing an agency action was highly deferential, but courts have developed that review into the reasoned decision-making standard or hard-look review, which is much less forgiving of agency decision-making. See Merrick B. Garland, Deregulation and Judicial Review, 98 HARV. L. Rev. 505, 525 (1985) (describing the emergence of hard-look review); See also Cass R. Sunstein, Reviewing Agency Inaction After Heckler v. Chaney, 52 U. CHI. L. REv. 653, 668-69 n.99, 671 (1985) (explaining that courts now require reasoned decision-making instead of the originally deferential interpretation of arbitrary and capricious review). In this Article, I use the terms "arbitrary and capricious," "reasoned decision-making," and "hard-look" interchangeably.

3. Christopher F. EdLEy, JR., Administrative LaW: Rethinking Judicial Control of BUREAUCRACY 72, 187-89 (1990).

4. Id.

5. Elena Kagan, Presidential Administration, 114 HARV. L. REV. 2245, 2331-39 (2001).

6. Id. at 2380-81.

7. Kathryn A. Watts, Proposing a Place for Politics in Arbitrary and Capricious Review, 119 YALE L.J. 2 (2009). In addition, Nina Mendelson has written on how administrative law should be structured to make presidential influence on agency rulemaking sufficiently transparent to justify allowing agencies to rely on such influence. See generally Nina A. Mendelson, Disclosing "Political" Oversight of Agency Decision Making, 108 Mich. L. REV. 1127 (2010) [hereinafter Mendelson, "Political" Oversight]. Mendelson takes a guarded approach to the question Watts poses about whether agencies should be able to rely on "political reasons" to justify rules. See id. at 1172-74 (suggesting that courts should be especially deferential to presidential preferences that reflect value choices but not to presidential influence that biases an agency's consideration of technical or legal criteria). To the extent that Mendelson's proposal would either increase deference to agency rulemaking when presidential influence has been properly disclosed or would have courts review the propriety of political influences on agency rulemaking, this Article lays out why I disagree. See id. at $1172-75$. To the extent that she advocates only mandatory disclosure of White House communications that relate to rulemaking procedures, this article does not directly address her proposal. See id. at $1163-66$. 
political discretion and permitting judges, if so disposed, to impose arbitrarily stringent standards of comprehensive rationality." Some recent Supreme Court opinions have reinforced this perception by seemingly rejecting political influence as a legitimate basis for agency action. For example, the majority in Massachusetts v. EPA rejected President Bush's political agenda as sufficient to justify the EPA's refusal to regulate greenhouse gas emissions. . Similarly, Justice Breyer's dissent in Fox Television suggested that the election of a new president is not an appropriate basis for the FCC to change its policy about what constitutes indecent broadcasting. ${ }^{10}$ But dicta in Justice Scalia's plurality opinion in Fox Television, which rejected Breyer's position, ${ }^{11}$ cuts the other way. Thus, the question of the role of politics as a justification for agency action has incited the particular interest of at least three current Supreme Court justices as well as several well regarded academics. ${ }^{12}$ What makes this Article significant is that it argues that those on both sides in the debate have misinformed understandings of the foundation and role of hard-look review-understandings that greatly limit the potential benefits such review might impart. Hence, this Article has the potential to reshape the

8. EDLEY, supra note 3, at 193; see also Watts, supra note 7, at 12-13 (stating that "hard look review had failed to reflect" the "shift from an expert-based model of agency decisionmaking to a politically-based model"); Kagan, supra note 5, at 2380 (The hard look doctrine "reflects an ideal vision of the administrative sphere as driven by experts .... A revised doctrine would acknowledge ... a an alternative vision centered on ... a accountability provided by the President.”).

9. Massachusetts v. EPA, 549 U.S. 497, 533-34 (2007). Jody Freeman and Adrian Vermeule have read the majority opinion in Massachusetts v. EPA to signal that agency action must be justified by science and not political influences - a position which they support. Jody Freeman \& Adrian Vermeule, Massachusetts v. EPA: From Politics to Expertise, 2007 SUP. CT. REv. 51, 52-54, 66-67 (2007).

10. FCC v. Fox Television Stations, Inc., 556 U.S. 502 (2009) (Breyer, J., dissenting); see also Ronald M. Levin, Hard Look Review, Policy Change, and Fox Television, 65 U. Miami L. Rev. 555, 561 n.35 (2011) [hereinafter Levin, Hard Look Review] (reading Breyer's opinion to "suggest[] that, because of the FCC's status as an independent agency, it should be relatively apolitical"). Some of Justice Breyer's academic writing might also be read to support the rejection of politics as a relevant consideration in agency decision-making. See, e.g., StePHEN BREYer, Breaking the Vicious CIRCLE: TOWARD EFFECTIVE RISK REgULATION 55-56 (1993) (“A depoliticized regulatory process might produce better results, hence increased confidence, leading to more favorable public and Congressional reactions.”).

11. Fox Television, 556 U.S. at 523-25.

12. Others who have weighed in on this issue include: Levin, Hard Look Review, supra note 10, at 561-62 (endorsing Watts's suggestion that a reformulated judicial review doctrine should give agencies enhanced opportunities to pursue political priorities); Glen Staszewski, Political Reasons, Deliberative Democracy, and Administrative Law, 97 IowA L. REv. 849, 875-77 (2012) [hereinafter Staszewski, Deliberative Democracy] (criticizing Watts' proposal from a deliberative democracy perspective); Richard J. Pierce, Jr., Political Control Versus Impermissible Bias in Agency Decisionmaking: Lessons from Chevron and Mistretta, 57 U. CHI. L. REV. 481, 497-98 (1990) (opining that agencies must be free to consider the policy preferences of Congress and the President when adopting rules). 
meaning and operation of hard-look review and, more particularly, to influence the Supreme Court's perception of the propriety of courts considering political influence in applying such review.

Watts has helped clarify precisely what is at issue in this debate. Of the works calling for judicial consideration of political influence within the hard-look paradigm, Watts's article provides the most focused and pragmatic exposition of the case for factoring politics into judicial review. Unlike prior advocates of this position, Watts suggests operational criteria for when and how judges should factor politics into review - that is, the precise nature of the kind of influence the courts should credit and the situations in which they should credit such influence. ${ }^{13}$ In addition, she identifies precise salutary effects that she believes such a change in hardlook review would have on agency rule-making. ${ }^{14}$ Thus, Watts's article provides a particularly meaningful foil against which to lay out my understanding of judicial review and the likely impact that allowing courts to consider politics would have on agency rulemaking.

For that reason, it was convenient to style this Article as a response to Watts's article. But, as I hope the Article makes clear, it is actually a broader exposition about the role of politics in agency decision-making and, more particularly, the proper place of political influence as a factor in hard-look review of rulemaking. ${ }^{15}$ In the broadest sense, this Article argues that those who have addressed the role of politics have confounded the question of the legitimacy of politics in rulemaking with that of the legitimacy of judicial consideration of politics in reviewing rulemaking. As I explain in Part I, Watts and her fellow critics of hard-look review are correct that courts have not credited citations to political influence in evaluating whether agency rulemaking meets the hard-look standard. But, contrary to the inference Watts draws, this does not reflect any hostility within the standard to such influence. In fact, the understanding of the administrative state that prompted courts to develop hard-look review accepts that agency decisions are political and properly so. In my view, however, the hard-look doctrine is a mechanism to ensure that agencies do not hide value judgments behind simple incantations that their actions are justified by political influence. Therefore, although politics may be a

13. Watts, supra note 7 , at $65-73$.

14. Id. at 33-45.

15. Hard-look review applies to all reviewable agency action, not just rulemaking. As Watts notes, political influence of agency action is especially defensible for rulemaking. Id. at 65-73. In cases involving agency adjudication, agency reliance on political considerations is arguably more problematic. See id. at $8 \mathrm{n}$.14. Hence, like Watts, I focus my arguments on judicial review of rulemaking and related agency actions, such as denials of petitions to institute rule-making. 
legitimate motivation for agency regulation, it should be irrelevant to judicial review of that regulation.

In Part II of this Article, I show how Watts's characterization of hardlook review's attitude toward politically motivated decisions leads her to conclude that judicial crediting of political explanations for agency rules results in outcomes superior to those under the current reasoned decisionmaking standard. It then explains why I believe this conclusion is erroneous. I continue in Part III of this Article to consider whether, given the insulation of courts from political accountability and their limited institutional capacity to evaluate political outcomes, it is appropriate to rely on them to distinguish legitimate from improper political influence.

\section{UNDERSTANDING REASONED DECISION-MAKING REVIEW}

\section{A. Watts's Understanding of the Reasoned Decision-Making Requirement}

According to Professor Watts, the current application of arbitrary and capricious review is problematic because courts do not consider agency appeals to political influence as legitimate reasons for regulation. ${ }^{16}$ She contends that review premised on this rejection of politics is at odds with the presidential control model that currently is in vogue in administrative law. ${ }^{17}$ That model posits that presidential control of agencies is justified by electoral accountability. ${ }^{18}$ Therefore, agency rules should reflect influence by the president on purely political grounds, at least where the president

16. Watts, supra note 7 , at 32 .

17. Id. at 39. Although most administrative scholars agree that presidential control is currently the predominant justification for the administrative state, many have expressed doubts about its theoretical basis and wisdom. See, e.g., Lisa Schultz Bressman, Beyond Accountability: Arbitrariness and Legitimacy in the Administrative State, 78 N.Y.U. L. REV. 461, 492-515 (2003) [hereinafter Bressman, Beyond Accountability]; Cynthia R. Farina, The Consent of the Governed: Against Simple Rules for a Complex World, 72 ChI.-Kent L. Rev. 987, 988 (1997); Staszewski, Deliberative Democracy, supra note 12, at 875; Matthew C. Stephenson, Optimal Political Control of the Bureaucracy, 107 Mich. L. REv. 53, 64 (2008); Peter L. Strauss, Overseer, or "The Decider"? The President in Administrative Law, 75 GEO. WASH. L. REV. 696, 702-03 (2007); see also infra note 19 and accompanying text. Nor am I aware of any court that has squarely relied on the presidential control model to justify a doctrine of administrative law. See generally Jodi L. Short, The Political Turn in American Administrative Law: Power, Rationality and Reasons, 61 DuKE L.J. 1811 (2012) (discussing at length the history leading to scholars' calls for political influence to justify agency action, but reporting no case in which a court relies on the presidential control model).

18. See Steven G. Calabresi, Some Normative Arguments for the Unitary Executive, 48 ARK. L. REV. 23, 35 (1995) (arguing that presidential control is superior to congressional control because the president is accountable to the entire electorate); Nina A. Mendelson, Rulemaking, Democracy, and Torrents of E-Mail, 79 GEO. WASH. L. REV. 1343, 1352 (2011) (noting that "recent scholarship has focused on the potential of presidential control to ensure that agencies exercise their discretion in a way that is democratically accountable"). 
publicly grounds his support for these rules in "public values," and where doing so does not lead the agency to act inconsistently with its authorizing statute. ${ }^{19}$ For Watts, like Edley and Kagan, the fact that such political influence of rulemaking is proper translates into her belief that agencies should be able to use that influence to bolster decisions that courts otherwise might find insufficiently reasoned. ${ }^{20}$

Watts supports this belief by suggesting that the reasoned decisionmaking standard that courts currently apply, while grounded in the "interest group model" of the administrative state, reflects vestiges of the "expertise model," which was used to justify the New Deal but has been criticized and not generally accepted since the adoption of the Administrative Procedure Act (APA) just after World War II. ${ }^{21}$ She goes on to note that increasingly the president is dictating agency policy. ${ }^{22}$ The president is a political actor, not a technocrat, and his preferences reflect politics, not technocratic expertise. In some cases, Congress, along with or instead of the president, exerts great influence on agency rulemaking. ${ }^{23}$ Therefore, Watts contends that it is best for the agency to report the actual motivation for its decision, which in many instances is that the change was requested by the president or adopted in response to congressional pressure. ${ }^{24}$ Because the president and Congress are elected, they will be held politically accountable for the agency's regulatory choices when an

19. See Kagan, supra note 5, at 2380-83; see also Jerry L. Mashaw, Prodelegation: Why Administrators Should Make Political Decisions, 1 J.L. ECON. \& ORG. 81, 94-95 (1985).

20. Watts, supra note 7, at 41-43; see also EDLEY, supra note 3, at 187-92 (generally implying that the reality of political influence on agency rulemaking translates into the propriety of judicial consideration of such influence); Kagan, supra note 5, at 2380-83 (proposing that courts read statutes to authorize the president to dictate rules for executive agencies and that courts show deference to such dictated rules). Thus, this Article is a rebuttal of Edley's and Kagan's work as well as that of Watts.

21. Watts, supra note 7, at 33-34; see also JAMES O. FrEEDMAN, CRISIS AND LEGITIMACY: THE AdMinistrative PROCESS AND AMERICAN GOVERNMENT 58-62 (1978) (noting the New Deal's emphasis on political independence to ensure agency pursuit of the public interest); MARTIN SHAPIRO, Who Guards the Guardians?: Judicial ConTROL OF ADMINISTRATION 60-63 (1988) (describing the New Deal conception of expert agencies and its fall from favor).

22. Watts, supra note 7, at 35-36.

23. See Jack M. Beermann, Congressional Administration, 43 SAN DiEgo L. Rev. 61, 64-65 (2006) (noting that Congress, as well as the president, is involved in "day to day administration of the law"). See generally Matthew D. McCubbins, Roger G. Noll \& Barry R. Weingast, Structure and Process, Politics and Policy: Administrative Arrangements and the Political Control of Agencies, 75 VA. L. REV. 431 (1989) (explaining how administrative procedures allow Congress to influence agency policy).

24. Watts, supra note 7, at 32-33, 35-37, 78; see also Kagan, supra note 5, at 2272-303 (describing the mechanisms used by Presidents Reagan through Clinton to control administrative action); Barry R. Weingast \& Mark J. Moran, Bureaucratic Discretion or Congressional Control? Regulatory Policymaking by the Federal Trade Commission, 91 J. PoL. ECON. 765, 768-70 (1983) (describing how changes in the makeup of Congress affected FTC policy). 
agency relies on public expressions of a desired regulatory outcome by the president or Congress. ${ }^{25}$ Hence, judicial review should reflect the reality that drives agency decisions. ${ }^{26}$ She contends that arbitrary and capricious review should be made more like review of agency statutory interpretation under Chevron, which she claims reflects the political control model of the administrative state. ${ }^{27}$ Although Watts tries to suggest otherwise, in doing so she essentially advocates for permitting agencies to substitute political influence for some of the analysis that courts would otherwise require under hard-look review. ${ }^{28}$

25. See Watts, supra note 7, at 35-37 (describing scholars' acceptance of the political control model as providing democratic accountability).

26. See id. at 33-39. Those, like Watts, who advocate judicial consideration of the president's influence on rulemaking may overstate the extent to which politics actually dictates agency action. For example, Kagan intimates that FDA regulation of cigarettes was adopted at the behest of President Clinton. Kagan, supra note 5, at 2282-83. According to the account by David Kessler-the head of the FDA who promulgated the regulation-President Clinton signed off on an already ongoing FDA effort to regulate tobacco, which he then made a salient part of his public regulatory agenda. DAVID

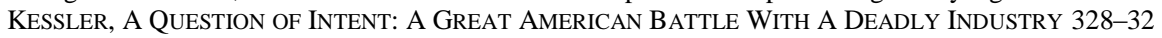
(2001).

27. Watts, supra note 7, at 37-38, 77-78, 84. One can read isolated excerpts of Chevron to support that it reflects the presidential control model. See, e.g., Chevron, U.S.A., Inc. v. Natural Res. Def. Council, Inc., 467 U.S. 837, 865 (1984) ("While agencies are not directly accountable to the people, the Chief Executive is, and it is entirely appropriate for this political branch of the Government to make such policy choices ..."). This reading, however, is undermined by the fact that Chevron seems to permit reasoned decision-making review at step two. See id. at 844 (holding that where the relevant statutory provision is ambiguous, "a court may not substitute its own construction of a statutory provision for a reasonable interpretation made by the administrator of an agency[,]" unless the interpretation is "arbitrary, capricious, or manifestly contrary to the statute"); Massachusetts v. Sebelius, 638 F.3d 24, 33-36 (1st Cir. 2011) (applying hard-look review at step two); see also Judulang v. Holder, 132 S. Ct. 476, 483 n.7 (2011) (stating that the analysis under step two of Chevron is the same "in substance" as that under arbitrary and capricious review); Kenneth A. Bamberger \& Peter L. Strauss, Chevron's Two Steps, 95 VA. L. Rev. 611, 625 (2009); Gary S. Lawson, Commentary, Reconceptualizing Chevron and Discretion: A Comment on Levin and Rubin, 72 CHI.KENT L. REV. 1377, 1378 (1997); For additional discussion of cases applying the reasoned decisionmaking standard at step two, see Ronald M. Levin, The Anatomy of Chevron: Step Two Reconsidered, 72 ChI.-Kent L. ReV. 1253, 1265 n.53, 1267 (1997). Finally, given that the Court had just decided State Farm the prior year and that the Chevron opinion gives no indication that the Court understood that it was making major changes in administrative law, it seems unlikely that Chevron was meant to endorse political control of agency rulemaking. See Thomas W. Merrill, The Story of Chevron: The Making of an Accidental Landmark, in AdMINISTRATIVE LAW STORIES 398, 420 (Peter L. Strauss ed., 2006) (concluding that the Court saw Chevron as a routine case and that its opinion merely restated established doctrine); see also Jamison E. Colburn, Waters of the United States: Theory Practice and Integrity at the Supreme Court, 34 FLA. ST. U. L. REV. 183, 207 n.122 (2007) (arguing that the accountability of the president was one of three rationales on which Chevron based its demand for deference, and that this rationale is inconsistent with the other two).

28. Hard-look review essentially requires an evaluation of the agency's explanation of the reasoning supporting its decision. See Matthew C. Stephenson, A Costly Signaling Theory of "Hard Look" Judicial Review, 58 ADMIN. L. REV. 753, 758-59 (2006) [hereinafter Stephenson, "Hard Look" Judicial Review]. Thus, although Watts asserts that she is not advocating that politics substitutes for agency analysis, the fact that her proposal would require a court to affirm an agency action 


\section{B. My Understanding of the Reasoned Decision-Making Requirement}

A major problem with Watts's critique is that she fails to distinguish the legitimate motivations for agency rulemaking from the factors that courts may consider when determining whether it is arbitrary and capricious. That is, Watts seems to believe that because the hard-look doctrine does not consider agency proffers of political influence as relevant to judicial review that doctrine rejects the validity of political influence. ${ }^{29}$ My understanding is that hard-look review is structured to separate agency value judgments, which courts concede can be based on politics, from the empirical predicates that underlie any particular rule, which should be based on objective analysis. Contrary to Professor Watts's contention, invocation of political reasons to justify a rule under hard-look review is not forbidden; it is simply irrelevant.

This point is crucial because it highlights Watts's (as well as Edley's and Kagan's) characterization of judicial review currently as antagonistic to political decision-making. As I explain below, reasoned decisionmaking review is not a vestige of the expertise model of the administrative state, but rather is premised on the interest group model of the

accompanied by proper invocation of political influence without explanation otherwise sufficient to pass hard-look review means that politics would substitute for analysis. See infra notes 154-56 and accompanying text; see also Enrique Armijo, Politics Rulemaking, and Judicial Review: A Response to Professor Watts, 62 ADMIN. L. REV. 573, 576 (2010) (opining that "the notion that ... political influence would be used only as a 'tiebreaker' when an agency record would support several proposed courses of action ... is specious").

29. Although Watts does not assert this directly, her characterization of hard-look review's intolerance of political influence is most evident in her argument that allowing courts to factor politics into judicial review would bring "[g]reater [c]oherence to [a]dministrative [l]aw's [v]acillation [b]etween [e]xpertise and [p]olitics." Watts, supra note 7, at 33-39. In that section of her article, she concludes that her proposal would "better harmonize[] [hard-look review] with administrative law's current embrace of political decision-making." Id. at 39. If one does not read hard-look review as antagonistic to political influence of agency decision-making, there is no need for harmonization.

The assumption that the factors an agency can use to justify a decision to a court are the same as those it may rely on in making its decision unfortunately seems to be widely shared, even by those who are uncomfortable with use of politics to justify agency regulation. See, e.g., Staszewski, Deliberative Democracy, supra note 12, at 859 ("If the fundamental goal of administrative law is to ensure that the policy choices of agencies are subject to the control of the president and ultimately reflect his preferences, it would be strange if agencies were precluded by law from expressly justifying their policy choices on this very basis.”); Freeman \& Vermeule, supra note 9, at 51-52 (concluding that Massachusetts v. EPA, which required the EPA to justify its refusal to regulate greenhouse gasses on technical grounds, signaled that agencies could not rely on politics in reaching its decision); Mendelson, "Political" Oversight, supra note 7, at 1171 (asserting that if agencies disclosed political reasons, "[j]udges . . . would need to take account of those reasons"); Richard J. Pierce, Jr., What Factors Can an Agency Consider in Making a Decision, 2009 MiCH. ST. L. REV. 67, 67 (2009) [hereinafter Pierce, What Factors Can an Agency Consider] (asserting that the courts confront the issue of the "factors that an agency must, can, and cannot consider" every day). 
administrative state, which accepts that agency action will and should reflect politics. $^{30}$ In fact, this acceptance of politics as part of administrative decision-making, together with the judiciary's recognition that its role is not to engage in weighing of political choices, explains why hard-look review must focus on non-political explanations for rulemaking. ${ }^{31}$ Essentially, one role of hard-look review is to facilitate political accountability by demanding that an agency make manifest the trade-offs generated by its rulemaking. The acceptance of agency politics by the interest group model, which is the impetus for this role of hard-look review, directly implies that such review is relevant to the political control model as well.

Before proceeding to marshal evidence for my reading of hard-look review however, I need to clarify the sense in which I mean that such review accepts political decision-making. According to my conception of hard-look review, politics is an acceptable justification for agency action to the extent it invokes the value judgments of those in power about the trade-offs inherent in such action. ${ }^{32}$ Hence, the fact that an administration holds an ideology that leads it to weigh the costs and benefits of a rule differently from a prior administration is a valid basis for changing the rule. What is not allowed under hard-look review is invocation of what Watts calls raw politics, by which she means an assertion that a rule is justified simply because it is preferred by the current group in power or their supporters - that is, because it makes the politically winning coalition better off regardless of its effects on others. ${ }^{33}$ Such a justification for a rule

30. For a description of these models, see generally Richard B. Stewart, The Reformation of American Administrative Law, 88 HARV. L. REV. 1667 (1975) or Mark Seidenfeld, A Civic Republican Justification for the Bureaucratic State, 105 HARV. L. REV. 1511, 1518-22 (1992) [hereinafter Seidenfeld, Civic Republican].

31. The judiciary's recognition of its non-political role is consistent with my reading of Chevron, see Mark Seidenfeld, Chevron's Foundation, 86 Notre DAME L. Rev. 273, 289-94 (2011) [hereinafter Seidenfeld, Chevron's Foundation], and helps explain the Court's issuance of that opinion only a year after State Farm adopted the reasoned decision-making standard of review. See Motor Vehicle Mfrs. Ass'n v. State Farm Mut. Auto. Ins. Co., 463 U.S. 29, 42-43 (1983) (describing the reasoned decision-making standard of review).

32. See Antonin Scalia, Chairman's Message: Rulemaking as Politics, 34 ADMIN. L. Rev. xxv, xxv-xxvii (1982) [hereinafter Scalia, Rulemaking as Politics] (pre-State Farm remarks asserting that, although not reflected in judicial doctrine, courts have allowed agencies to factor "what the public wants" - as reflected through the political influence of the president, Congress, and interest groups on agencies-into its rulemaking decisions); Levin, Hard Look Review, supra note 10, at 562; Mendelson, "Political" Oversight, supra note 7, at 1137-38, 1146-57 (stating that presidential influence should be seen as appropriate for "value-laden decisions").

33. See Watts, supra note 7, at 54-55. The distinction between accounting for values of the current administration and not relying on raw politics is subtle but crucial. Perhaps the distinction is best summed up as the distinction between the agency doing what it believes to be best based on its 
violates the requirement that agency action not be arbitrary. ${ }^{34}$ In this sense, Watts is correct that hard-look review is dismissive of politics, but only of the kind of politics that cannot validly justify agency action.

As importantly however, hard-look review does not reject a rule because it is politically motivated, even if that motivation is a self-serving and venal political calculation. ${ }^{35}$ Hard-look review accepts politically motivated rules because it concerns itself with justification, not motivation. A policy that is motivated by the president's desire to provide benefits to his political supporters may nonetheless be defensible as good policy. ${ }^{36}$ This is implicitly recognized under the principle of administrative regularity, which in relevant part holds that courts will not second guess whether the reasons an agency gives for its decision are the actual reasons that motivated the decision. ${ }^{37}$ As will become clear when I discuss the details of hard-look review, I read the cases to say that courts will reject an

evaluations of trade-offs versus the agency doing what it knows is not best simply to give those in power what they desire. See FCC v. Fox Television Stations, Inc., 556 U.S. 502, 515 (2009) (holding that hard-look review does not require an agency to prove that its policy is best, the agency need only show why it believed the policy to be best).

34. See Bressman, Beyond Accountability, supra note 17, at 474 (reporting that the "judicial innovation" of forcing "agencies to substantiate their decisions with a public rationale to prevent deviation for nonpublic purposes" was meant to prevent against arbitrary agency action). Prohibition of agency reliance on mere preferences of those in power is consistent with a deliberative democratic view of administrative agencies, which requires that agency action further the public interest rather than simply the interests of those in power because they are in power. See Staszewski, Deliberative Democracy, supra note 12 , at $857-58,887-88$. One must be careful to recognize however, that desires to benefit one subgroup of the citizenry at the expense of others can be in the public interest if there is a public regarding justification for providing such benefit. See Seidenfeld, Civic Republican, supra note 30 , at 1532 .

35. See, e.g., Sierra Club v. Costle, 657 F.2d 298, 409 (D.C. Cir. 1981) (suggesting that West Virginia Senator Robert Byrd's attempt to get the EPA to consider jobs in the Eastern United States coal belt was not improper); see also Antonin Scalia, The Role of the Judiciary in Deregulation, 55 ANTITRUST L.J. 191, 197 (1986) [hereinafter Scalia, Role of the Judiciary] ("When we review the rule, all that we judges really say is, "Well, if a person was only using these factors set forth in the statute and trying to do it analytically, a person could come out with this result. It is within the bounds of the acceptable.' But, we are not saying that is the real reason they came to that result.").

36. The confusion of motivation with justification lies at the heart of the genetic fallacy. See Michael Moore, Moral Reality, 1982 WIS. L. REV. 1061, 1098 n.89 (1982) ("The fallacy is so named because it conflates the genesis of a view with the grounds on which the view is judged to be true or false... . A common example of the genetic fallacy [occurs when one] .... attempt[s] to discredit the views of another ... by showing that she had disreputable motives for holding them."). Watts seems to succumb to this fallacy to the extent she wants the courts to credit political influence on rulemaking when it appears to have motivated the agency to act. See Watts, supra note 7, at 84. But, she is in good company as most scholars of judicial review of agencies assume that justifications reflect the actual motivation for agency decisions. See supra note 29.

37. See United States v. Morgan, 313 U.S. 409, 422 (1941); San Luis Obispo Mothers for Peace v. United States Nuclear Regulatory Comm'n, 789 F.2d 26, 44-45 (D.C. Cir. 1986); see also Scalia, Role of the Judiciary, supra note 35, at 197 ("If somebody tells us that isn't the real reason, then we will kick it away."). 
agency value judgment underlying a decision only in the extremely rare instance when those judgments are so implausible that no one could reasonably conclude that the trade-offs inherent in the adoption of a rule are socially beneficial. Thus, hard-look review does not second guess legitimate policy decisions by agencies that are motivated by raw politics, but does prohibit decisions that cannot be justified by anything other than raw politics.

\section{The Expertise Model and Judicial Review}

The expertise model of the administrative state was developed to enable the progressive agenda and ultimately the New Deal to escape both political influence, ${ }^{38}$ which often reflected the power of those who controlled business, and judicial interference, ${ }^{39}$ which had stymied the progressive agenda by finding that agenda inconsistent with economic rights of property and contract. ${ }^{40}$ The expertise model attempted to eliminate political influence by characterizing the issues that came before agencies as non-political. ${ }^{41}$ To do so, the model assumed that seemingly value-laden decisions were not controversial if viewed from the perspective of the professionals on agency staffs who made these decisions. ${ }^{42}$ Essentially, the model viewed agencies as politically disinterested entities comprised of professionals whose decisions are driven by their professional knowledge and training. The idea was very much the way people used to think of doctors in a much simpler and more trusting time. ${ }^{43}$ If you were sick, you went to the doctor; he examined you, figured out what was wrong, and prescribed the cure. ${ }^{44}$ No one questioned whether there was a better treatment, let alone whether the doctor's action

38. See FREEDMAN, supra note 21, at 59-60 (reviewing Progressive and New-Deal-era rationales for granting agencies independence from the political process).

39. See Emily Hammond Meazell, Super Deference, The Science Obsession, and Judicial Review as Translation of Agency Science, 109 MiCH. L. REv. 733, 756-57 (2011) (under the expertise model, "[j]udicial review was characterized by great deference").

40. See A.C. Pritchard \& Robert B. Thompson, Securities Law and the New Deal Justices, 95 VA. L. REV. 841, 872 (2009) (stating that "[t]he Supreme Court . . . was perceived as hostile to government regulation, invoking constitutional rights of personal liberty and due process to block high profile New Deal initiatives").

41. See Stewart, supra note 30, at 1678

42. See Seidenfeld, Civic Republican, supra note 30, at 1519.

43. See Michael Betz \& Lenahan O'Connell, Changing Doctor-Patient Relationships and the Rise in Concern for Accountability, 31 SOC. PROBS. 84, 85 (1983) (noting a marked decline in patient trust of doctors after the "golden age of medicine," from 1910 to 1950).

44. See L.M.L. Ong et al., Doctor Patient Communication: A Review of the Literature, 40 Soc. SCI. MED. 903-05 (1982) (stating that prior to about 1962, the traditional doctor-patient relationship was paternalistic: the doctor directed care and made all decisions about treatment). 
was motivated by some interest he might have outside of the patient's welfare. ${ }^{45}$ Similarly, political influence in agency decision-making was seen as corrupting and biased when brought to bear on what were essentially professional questions about what needed to be done to cure the relevant ill that the agency was authorized to address. ${ }^{46}$ As a result, agencies needed to be insulated from politics. ${ }^{47}$ This insulation was achieved by creating multimember boards as agency heads, where no more than a bare majority of board members could come from any one party, and by creating tenure in the jobs of agency heads and staff, protecting them from being fired by the president except for cause. ${ }^{48}$

The progressive and New Deal movements also saw courts as interfering with agencies' abilities to cure society's ills. ${ }^{49}$ Courts at the time relied on rights, especially those of property and contract, to find social regulation beyond the powers of government. ${ }^{50}$ Hence, at the same time that Congress was creating the National Labor Relations Board, perhaps the quintessential New Deal agency, it was limiting the

45. See Betz \& O'Connell, supra note 43, at 91 (describing the rise of the medical accountability world view in which doctors are "self-interested vendors of medicine and as unworthy of trust as merchants").

46. See James M. Landis, The Administrative Process 142-43 (1938); Seidenfeld, Civic Republican, supra note 30, at 1513 (stating that "New Dealers . . asserted that agency decisions were applications of technical expertise, best made outside an environment influenced by interest groups and the political process").

47. See LANDIS, supra note 46, at 113-14; Joseph B. Eastman, A Twelve Point Primer on the Subject of Administrative Tribunals, in SELECTED PAPERS AND ADDRESSES OF JOSEPH B. EASTMAN, 1942-44, at 375 (G. Lloyd Wilson ed., 1948). For a general description of the influence of the expertise model on administrative law, see Stewart, supra note 30, at 1676-81.

48. Rachel E. Barkow, Insulating Agencies: Avoiding Capture Through Institutional Design, 89 TEX. L. REV. 15, 17 (2010) (describing traditional independent agency structure as including "a multimember commission with for-cause removal protection"); Neal Devins \& David E. Lewis, NotSo Independent Agencies: Party Polarization and the Limits of Institutional Design, 88 B.U. L. REv. 459, 463 (2008) (stating that independent agencies are characterized by "long commissioner tenure, staggered terms, and political insulation ... to facilitate a non-political environment where regulatory experts can apply their knowledge to complex policy problems"); see also Marshall J. Breger \& Gary J. Edles, Established by Practice: The Theory and Operation of Independent Federal Agencies, 52 ADMIN. L. REV. 1111, 1113 (2000) (noting that independent agencies "are 'independent' of the political will exemplified by the executive branch, yet they are also multi-member organizations, a fact that tends toward accommodation of diverse or extreme views through the compromise inherent in the process of collegial decisionmaking").

49. See John Dinan, Court-Constraining Amendments and the State Constitutional Tradition, 38 RUTGERS L.J. 983, 989 (2007) (noting that "numerous state court decisions . . . were viewed by Progressive reformers as blocking enactment of important policies"); Pritchard \& Thompson, supra note 40 (explaining that New Dealers saw the courts as a potential barrier to their experimentation with the regulatory state).

50. See Paul Kens, Lochner v. New York: Economic Regulation on Trial 155-57 (1998). 
jurisdiction of courts to entertain suits for labor injunctions ${ }^{51}$ and otherwise trying to discourage courts from declaring progressive legislation unconstitutional under Lochner-era substantive due process. ${ }^{52}$ Therefore, the only role for the courts under the expertise model was to delineate the outer bounds of agency authority and to check that agency regulation did not grossly transgress those bounds ${ }^{53}$ Drawing on my prior analogy to doctors as professionals, the model wanted to make sure that the doctors did not decide to sell patients insurance instead of providing medical care. Obviously, this standard of review is a far cry from the hardlook test that Watts criticizes.

\section{Reasoned Decision-Making and the Interest Group Model}

Review for reasoned decision-making, not surprisingly, is best explained by the interest group model of the administrative state. ${ }^{54}$ This was probably the most prevalently accepted justification for rulemaking in the early 1970s, when courts developed the hard-look doctrine. ${ }^{55}$ The

51. The National Labor Relations Act (NLRA), a lynchpin of the New Deal, transferred power over labor policy from the courts to an agency because courts were seen as unduly hostile to labor interests. FELIX FRANKFURTER \& NATHAN GREENE, THE LABOR INJUNCTION 134-98 (1930); Rebecca Hanner White, Time for a New Approach: Why the Judiciary Should Disregard the "Law of the Circuit" When Confronting Nonacquiescence by the National Labor Relations Board, 69 N.C. L. REv. 639, 651-52 (1991).

52. New Dealers' frustration with the courts even prompted President Franklin Roosevelt to propose his oft-noted court-packing plan. Barry Friedman, The History of the Countermajoritarian Difficulty, Part Four: Law's Politics, 148 U. PA. L. REv. 971, 990-96, 1010 (2000).

53. See Stewart, supra note 30, at 1679-81; see also Seidenfeld, Civic Republican, supra note 30 , at $1518-19$.

54. See Thomas W. Merrill, Capture Theory and the Courts: 1967-1983, 72 CHI.-Kent L. REV. 1039, 1039-44, 1059-67 (1997); Gillian E. Metzger, Ordinary Administrative Law as Constitutional Common Law, 110 Colum. L. REv. 479, 491 (2010). To the extent the doctrine requires that agencies provide an opportunity for transformative dialogue and ultimately justify regulations based on something other than raw politics, one can argue that it also embodies principles of deliberative democracy. See Glen Staszewski, Rejecting the Myth of Popular Sovereignty and Applying an Agency Model to Direct Democracy, 56 VAND. L. REV. 395, 443-47 (2003) (explaining how notice and comment procedures and hard-look review "encourage and enforce" the ideals of deliberative democracy); Cass R. Sunstein, Interest Groups in American Public Law, 38 STAN. L. REV. 29, 61-63 (1985) (explaining how hard-look review facilitates the goals of deliberative democracy).

55. The hard-look test was first announced in Greater Boston Television Corp. v. FCC, 444 F.2d 841, 851 (D.C. Cir. 1970). It developed over the following decade, influenced perhaps by the legislatively demanded inquiry into an agency's consideration of environmental impacts of its decisions under National Environmental Policy Act (NEPA). Mark Seidenfeld, Demystifying Deossification: Rethinking Recent Proposals to Modify Judicial Review of Notice and Comment Rulemaking, 75 TEX. L. REV. 483, 493 n.59 (1997) [hereinafter Seidenfeld, Demystifying Deossification]; see also Robert L. Rabin, Federal Regulation in Historical Perspective, 38 STAN. L. REV. 1189, 1298-99 (1986) (explaining how both NEPA and hard-look review developed from an expectation that agencies broaden their regulatory perspectives). 
interest group model was the predominant legal view when the Supreme Court signed onto the reasoned decision-making standard in State Farm in $1983 .^{56}$

That model views government suspiciously because of its susceptibility to being used to provide rents to special interest groups. ${ }^{57}$ According to the interest group model, the Madisonian notion of faction counteracting faction is complicated by the fact that some factions have advantages over others. In the regulatory arena, regulated entities control relevant information and thus do not bear the same costs in order to participate in the regulatory process. ${ }^{58}$ Those with focused interests, which often also correspond to the regulated entities, have the advantage of lower costs of organizing and coordinating action. ${ }^{59}$

On top of all of this, according to the interest group model, agencies are prone to capture because they are structured to advantage regulated entities. ${ }^{60}$ Agency staff members often share the professional background of the employees of the companies they regulate and in many instances interact closely with their industry compatriots on a day-to-day basis. ${ }^{61}$

56. The interest group model of administrative law ascended to the predominant judicial view in the 1970 s and the presidential control model began to replace it only after President Reagan implemented stronger executive branch controls over rulemaking in 1982. See Lisa Schultz Bressman, Procedures as Politics in Administrative Law, 107 ColuM. L. REv. 1749, 1761-66 (2007) [hereinafter Bressman, Procedures as Politics]. Legal scholars, however, did not begin to advocate that model as a justification for the administrative state at least until Jerry Mashaw's article in 1985 advocating delegation because of the unique position of the president as answerable to the entire polity. See Mashaw, supra note 19, at 95-96.

57. See Einer R. Elhauge, Does Interest Group Theory Justify More Intrusive Judicial Review?, 101 YALE L.J. 31, 43 (1991) (finding the "disproportionate influence of well-organized interest groups [to be] disturbing"); Jide O. Nzelibe \& Matthew C. Stephenson, Complementary Constraints: Separation of Powers, Rational Voting, and Constitutional Design, 123 HARV. L. REV. 617, 625-26 (2010) (describing as pessimistic the view that separation of powers encourages Congress to delegate regulatory authority to agencies to enable them to deliver rents to special interest groups).

58. See Michael E. Levine \& Jennifer L. Forrence, Regulatory Capture, Public Interest, and the Public Agenda: Toward a Synthesis, 6 J.L. ECON. \& ORG. 167, 176-77 (1990) (noting that special interest outcomes may result from differential levels of "information, organization, and transaction and monitoring costs").

59. See Mancur Olson, The Logic of Collective Action: Public Good and the Theory OF GROUPS 29 (1980).

60. See Jonathan R. Macey, Promoting Public-Regarding Legislation Through Statutory Interpretation: An Interest Group Model, 86 COLUM. L. ReV. 223, 263-64 (1986) (describing the theory of regulatory capture); Mathew D. McCubbins, Roger G. Noll \& Barry R. Weingast, Administrative Procedures as Instruments of Political Control, 3 J.L. ECON. \& ORG. 243, 247 (1987).

61. See Seidenfeld, Civic Republican, supra note 30, at 1555 (noting that the shared professional backgrounds between agencies and those they regulate can result in parochial biases, but that judicial review and staff structure can counteract this problem); Seidenfeld, Demystifying Deossification, supra note 55, at 510 (explaining how hard-look review "encourages agencies to obtain . . . input from various professional perspectives. ... [which] discourages rules that reflect a biased or parochial view of the public interest"). 
Even when a diffuse interest group is able to secure legislative benefits, or at least a compromise with opposing special interest groups within the legislative arena, the diffuse group may lose what the statute granted it because focused interest groups have greater influence over the statute's implementation. ${ }^{62}$ Thus, the interest group model of the administrative state both cautions against making it too easy for the government to act and seeks legal requirements for agency action that will help to equalize the playing field in the regulatory arena.

The doctrinal details of the reasoned decision-making standard respond to the cautionary message of the interest group model. The standard is essentially process based; it does not demand that outcomes meet any particular substantive standard. ${ }^{63}$ To meet the standard, an agency must justify any decision to adopt a rule by, among other things, addressing factors that are relevant to its decision. ${ }^{64}$ It must reveal the data on which it relies as well as the assumptions it makes in analyzing that data. ${ }^{65}$ It must show how its factual determinations and predictions follow from the data in its decision-making record. In rulemaking, if a commenter introduces relevant data or proposes alternatives to the agency's action that plausibly can better serve the purposes of the enabling act, the agency must consider the data and alternatives and explain why they did not lead the agency to a different outcome. ${ }^{66}$ This burden of explanation may require the agency to

62. See Eric Biber, The Importance of Resource Allocation in Administrative Law, 60 ADMIN. L. REV. 1, 40-47 (2008) (explaining how "agency failures to implement regulatory statutes may be the result of asymmetries in the ability of regulatory subjects and regulatory beneficiaries to monitor and influence the political process"); see also R. SHEP MELNICK, REgulation AND THE COURTS: THE CASE OF THE ClEAN AIR ACT 198-99 (1983) (describing EPA regional offices as giving violators "time to receive and install requisite control equipment," allowing "firms in financial trouble to phase in expensive controls," and sometimes even allowing "a firm to operate a facility" in violation of permit requirements "while it [builds] a replacement facility").

63. See Bressman, Procedures as Politics, supra note 56, at 1779; Gary Lawson, Outcome, Procedure and Process: Agency Duties of Explanation for Legal Conclusions, 48 RUTGERS L. REV. 313, 318-19 (1996) (noting that reasoned decision requirement relates to agency process); Mark Seidenfeld, Cognitive Loafing, Social Conformity, and Judicial Review of Agency Rulemaking, 87 CoRnell L. REV. 486, 518 (2002) [hereinafter Seidenfeld, Cognitive Loafing] (explaining that "[t]he 'hard-look' or 'relevant factors' rubric . . . is almost entirely a process-based evaluation").

64. See Elizabeth Magill \& Adrian Vermeule, Allocating Power Within Agencies, 120 YALE L.J. 1032, 1053 (2011) (stating that hard-look review "forces agencies to ensure both that their decisions are scientifically and technocratically defensible and that those decisions rest on a plausible legal account of which factors are statutorily relevant").

65. See Catherine M. Sharkey, Federalism Accountability: "Agency-Forcing” Measures, 58 DUKE L.J. 2125, 2181 (2009) (noting that hard-look review is meant "to ensure that agencies disclose relevant data and provide reasoned responses to material objections raised during the rulemaking process").

66. See Thomas O. McGarity, Some Thoughts on "Deossifying" the Rulemaking Process, 41 DUKE L.J. 1385, 1410 (1992) (explaining that "a reviewing court [is] obliged . . . to determine whether the agency applied the correct analytical methodology, applied the right criteria, considered the 
flesh out the information introduced into the record by a commenter to allow a court to determine whether the information warranted more careful consideration of an alternative by the agency.

As numerous articles have noted, hard-look review increases an agency's cost of adopting a rule and slows down the agency decisionmaking process, sometimes quite markedly. ${ }^{67}$ Whether such an increase in costs and delay are good or bad may depend on the precise circumstances surrounding the rulemaking. ${ }^{68}$ But, such delay and the increase in rulemaking costs can be seen as a substitute for the inertia built into the legislative process by bicameralism and presentment, requirements that agency rulemaking sidesteps. ${ }^{69}$

Hard-look review also guards against an agency deviating from its statutory charge. Statutes may authorize an agency to act within a prescribed set of circumstances; simultaneously, the same statutes frequently limit the scope of agency action or demand that the action further particular regulatory ends. ${ }^{70}$ Statutes may also require an agency to

relevant factors, chose from among the available range of regulatory options, relied upon appropriate policies, and pointed to adequate support in the record for material empirical conclusions"); see also Short, supra note 17, at 1819-20 (noting that the rationalist view of hard-look review "places the onus on the agency (1) to document reasons for its decisions; (2) to compile evidence supporting those reasons; (3) to consider, analyze, and reject contrary evidence; and (4) to consider, analyze, and reject important alternatives to its preferred policy based on the available evidence").

67. See, e.g., JerRy L. MASHAW \& DAVID L. HARFSt, The StrugGle For Auto SAFETy 22454 (1990); McGarity, supra note 66, at 1400-03; Richard J. Pierce, Jr., The Unintended Effects of Judicial Review of Agency Rules: How Federal Courts Have Contributed to the Electricity Crisis of the 1990s, 43 ADMIN. L. REv. 7 (1991); see also Stephenson, "Hard Look" Judicial Review, supra note 28, at 766 (arguing that the increase in costs imposed on the agency by hard-look review allows the agency to signal which rules it expects will provide the greatest benefits).

68. See generally Mark Seidenfeld, Why Agencies Act: A Reassessment of the Ossification Critique of Judicial Review, 70 OHIO. ST. L.J. 251 (2009) [hereinafter Seidenfeld, Why Agencies Act].

69. The "cumbersome process of bicameralism and presentment serves several related interests: It makes it more difficult for 'factions' to capture the legislative process; it restrains passion and promotes deliberation ... and it creates a bias in favor of filtering out bad laws by raising the decision costs of passing any law.” John F. Manning, Nonlegislative Rules, 72 GEO. WASH. L. REV. 893, 899 (2004). Notice and Comment procedures serve these same interests. Id. at 944 ("[L]awmaking processes such as bicameralism and presentment or notice-and-comment rulemaking promote caution, deliberation, and accountability"); see also Glen Staszewski, Textualism and the Executive Branch, 2009 Mich. ST. L. REV. 143, 164 (2009) (contending that "statutes [implemented] pursuant to noticeand-comment rulemaking procedures ... arguably promote the underlying goals of bicameralism and presentment").

70. For example, the Housing Act of 1937 authorizes local housing agencies to evict tenants in federally subsidized public housing if the "public housing tenant, any member of the tenant's household, or any guest or other person under the tenant's control," engages in "drug related criminal activity on or off [the tenant's] premises." 42 U.S.C. $\S 1437 \mathrm{~d}(1)(6)$. This statute both authorizes evictions and limits the bounds to those provided by the statute. See Dep't of Hous. \& Urban Dev. v. Rucker, 535 U.S. 125 (2002). 
regulate in particular factual circumstances. ${ }^{71}$ Forcing the agency to explain the factual predicates for a rule and to tie them to the rulemaking record facilitates judicial review to ensure that the rule is consistent with the agency's statutory mandates or limitations.

Finally, hard-look review helps put less connected interest groups on the same footing in the administrative process as more focused groups like the regulated industry. At least a priori, an agency must treat data, suggested alternatives, and arguments from all interested persons with equal respect. ${ }^{72}$ An agency acts at its own peril if it ignores comments that it finds unsophisticated or unpersuasive because it has no way of knowing whether the reviewing court will find those comments relevant to the agency determination. ${ }^{73}$ Interest groups with less access to information about the entity or matter being regulated often can burden the agency to generate information simply by raising issues about the agency data or preferred outcome. And the agency at least must explain the predicted impact of the action it takes, which reduces the costs to those who are not regular players in the regulatory arena of determining what is at stake in the proceeding.

The presidential control model has replaced the interest group model as the predominant justification for the administrative state. ${ }^{74}$ Like the interest group model, however, the presidential control model views politics as playing a legitimate role in administrative rulemaking. According to that model, the president, answering to the entire electorate,

71. For example, the Clean Air Act, requires that EPA "shall by regulation prescribe... standards applicable to the emission of any air pollutant from any class ... of new motor vehicles ... which in [the EPA Administrator's] judgment cause[s], or contribute[s] to, air pollution... reasonably. . . anticipated to endanger public health or welfare." 42 U.S.C. § 7521(a)(1). The Supreme Court read this statute to require that the EPA regulate greenhouse gases unless the EPA "determines that greenhouse gases do not contribute to climate change or ... provides some reasonable explanation as to why it cannot or will not exercise its discretion to determine whether they do." Massachusetts v. EPA, 549 U.S. 497, 533 (2007).

72. See Jonathan Weinberg, The Right to be Taken Seriously (Feb. 29, 2012), in Soc. SCI. RESEARCH NETWORK, 1-2, available at http://papers.ssrn.com/sol3/papers.cfm?abstract_id=2013567 (SSRN abstract and link to download paper) (noting that administrative agencies must engage any relevant comments and respond to them, which gives rise to a "right to be taken seriously").

73. See Richard J. Pierce \& Sidney A. Shapiro, Political and Judicial Review of Agency Action, 59 TEX. L. REV. 1175, 1190-91 (1981) (noting that judges can pick and choose which of scores or even hundreds of statutory factors were relevant); Seidenfeld, Why Agencies Act, supra note 68, at 300-01 (" $[F]$ actors that a judge on the reviewing court likely will find relevant to his determination of the acceptability of the agency action will depend significantly on the identity of the reviewing judge.").

74. See Bressman, Beyond Accountability, supra note 17, at 485-92; see also Farina, supra note 17, at 988; Staszewski, Deliberative Democracy, supra note 12, at 851. 
has incentives to act in the best interest of the country, ${ }^{75}$ which might suggest that there is no need for judicial review to counteract special interest group influence. But, any casual observer of politics knows that the president is not immune from influence of focused groups whose interests may not accord with those of the nation as a whole. ${ }^{76}$ The presidential control model therefore can avoid the problems of undue influence of special interest groups only if the actions of the president are transparent to the public in the strong sense that the public can understand the costs and benefits that presidential policies impose on the various interest groups that help focus the electorate's attention and ultimately deliver votes. And, experience with recent imperial presidents provides ample evidence that, without some mechanism to ensure such strong transparency, the president can obfuscate the extent to which he has influenced rulemaking. Even when the president's influence is recognized, the lack of transparency allows him to hide the effects of his policies. ${ }^{77}$ Thus, the presidential control model does not obviate the need for hardlook review.

\section{The Place of Politics in Reasoned Decision-Making}

Given the role of reasoned decision-making within the interest group model and by extension the presidential control model, the question remains: what is the proper place of politics within that standard of review? Unfortunately, language in both scholarship and opinions by Justice Breyer seem to support Watts's belief that judges are skeptical of political influence on agency decisions. ${ }^{78}$ But, a careful reading of Breyer's arguments leads me to believe that even his understanding of the hard-look standard does not condemn or even devalue the political choices that influence the agency decisions. ${ }^{79}$ Those influences are simply not relevant to the reviewing court's inquiry if the hard-look test is to provide

75. Kagan, supra note 5, at 2331-32; Mashaw, supra note 19, at 95.

76. See Nicholas Bagley \& Richard L. Revesz, Centralized Oversight of the Regulatory State, 106 Colum. L. Rev. 1260, 1306 (2006) (opining that the president is subject to the same interest group pressures as agency officials).

77. See Staszewski, Deliberative Democracy, supra note 12, at 867. Compare Bressman, Beyond Accountability, supra note 17, at 506-10 (criticizing Kagan's reliance on presidential control over agencies as insufficient to prevent unjustifiable regulation because of various mechanisms by which the administration could obfuscate the motivations and effects of its involvement); with Kagan, supra note 5, at 2337, 2383-84 (noting that presidential control will best reflect broad public sentiments when it is most visible, but concluding that having the president simply take responsibility for agency policies is sufficient transparency).

78. See supra note 10 and accompanying text.

79. See infra notes 120-21 and accompanying text. 
appropriate checks on agency action as required by the interest group model.

Like the model from which it derives, reasoned decision-making review recognizes that agency rulemaking will be inherently political in the sense that it will require an agency to make value judgments that are not strictly dictated by applying the law to a set of facts. ${ }^{80}$ The reasoned decision-making standard is exacting in that courts will look at the agency's explanation of its decision, often in excruciating detail, to ensure that the agency identified and explicitly considered all relevant factors in reaching its outcome. ${ }^{81}$ But the standard explicitly admonishes judges not to substitute their judgments for those of the agency. ${ }^{82}$ Underlying this admonition is the understanding that regulatory value judgments are not dictated by legally discernible standards and are therefore inherently political. ${ }^{83}$ The judiciary, being the branch least directly accountable to the polity, has no business second guessing such judgments. ${ }^{84}$ In essence, the arbitrary and capricious standard recognizes that the political arena is the appropriate forum for constraining value choices made by the agency in rulemaking. It does not deny that politics plays a legitimate and even vital role in agency choices, ${ }^{85}$ but it does recognize that courts are ill-suited to evaluate the bona fides of value choices and hence of political influence.

80. See Scalia, Role of the Judiciary, supra note 35, at 196-97; Seidenfeld, Civic Republican, supra note 30, at 1538-40; cf. Samuel G. Brooks, Note and Comment, FCC v. Fox Television Stations and the Role of Logical Error in Hard Look Review, 2010 BYU L. REV. 687, 698-99 (2010) (recognizing the distinction between what may motivate an agency decision and what may formally justify it and noting that "hard look review may not always effectively deter agencies from basing their decisions on political factors in practice").

81. See Jack M. Beermann \& Gary Lawson, Reprocessing Vermont Yankee, 75 GEO. WaSH. L. REV. 856, 880-81 (2007) (asserting that the "'hard-look' doctrine is generally quite rigorous and imposes a substantial burden on both agencies and courts").

82. Citizens to Preserve Overton Park, Inc. v. Volpe, 401 U.S. 402, 416 (1971) (The arbitrary and capricious review is "searching and careful, [but] the ultimate standard of review is . . narrow. ... [and] [t]he court is not empowered to substitute its judgment for that of the agency.").

83. See Scalia, Role of the Judiciary, supra note 35, at 196-97. The problem with courts imposing their value judgments in the absence of legal standards is explicitly recognized in the factors the Supreme Court uses to determine when a controversy is a nonjusticiable political question. See Baker v. Carr, 369 U.S. 186, 214, 217 (1962) (listing "lack of judicially discoverable standards" and "impossibility of deciding without an initial policy determination of a kind clearly for nonjudicial discretion" as two of six factors that identify nonjusticiable political questions).

84. See Seidenfeld, Chevron's Foundation, supra note 31, at 289. Article III includes an implicit premise that courts should "refrain[] from second guessing a decision by a political branch when doing so will require the court to rely heavily on policy." Id.

85. Glen Staszewski recently advocated that agencies should be able to use value judgments to justify a rule, but only when the outcome is close in terms of technical considerations. See Staszewski, Deliberative Democracy, supra note 12, at 899-912. In such a situation, he would require the agency to try to use the value judgments of the public as reflected in rulemaking comments but suggests that the ultimate value choice should be the agency's and that it would not be adequate to rely on that of 
Nonetheless, under the interest group model of the administrative state and, by extension, the presidential control model, ${ }^{86}$ there is a role for judicial review to facilitate proper operation of the political arena. Hardlook review serves this function by requiring the agency to separate the empirical findings and predictions underlying its action from the value choices inherent in that action. That is, the agency must describe and defend the impact its decision is likely to have relative to other possible regulatory paths it could have pursued. This description and its comparison to the impacts of alternative actions allow those interested in the decision to understand the trade-offs inherent in the agency's value choices without having to invest greatly in educating themselves about the technical details of the subject of regulation. ${ }^{87}$ Most significantly, however, it avoids imposing on an agency the reviewing court's perception of which value choices are legitimate and which are not.

the president. $I d$. at 884 . Although this sounds similar to my reading of what reasoned decision-making requires, it differs in some fundamental respects. First, I do not think that one can use technical criteria alone to winnow most rulemaking choices to close calls. The use of science itself involves value judgments and the prevalence of differences in how reasonable people evaluate trade-offs between rulemaking outcomes leads me to believe that agency decisions will virtually always rely to a great extent on value judgments. See Meazell, supra note 39, at 743. Second, the extent to which an agency can glean a public preference of values based on rulemaking comments is subject to biases in who participates in rulemaking and how. Relying primarily on such comments is therefore not a reliable indication of public values. See Mariano-Florentino Cuéllar, Rethinking Regulatory Democracy, 57 ADMIN. L. REV. 411, 412, 490-91 (2005) (reporting an empirical study showing that members of the public are interested in participating in rulemaking and that agencies take the diffuse public's interests into account, but the public's influence in rulemaking is limited by the inability to participate in a sophisticated manner); Mendelson, supra note 18, at 1372 ('There is a risk of 'astroturfing,' when groups form that purport to - but do not really — represent grassroots interests, potentially giving an agency an incorrect picture of public preferences."). Third, even adopting deliberative democracy as one's model for the administrative state, I do not see why the agency head should not be able to factor in the value judgments of the president in choosing the ultimate rule. See Levin, Hard Look Review, supra note 10, at 561 (stating, with respect to regulatory policy changes, that "elections should have consequences"). But see Evan J. Criddle, Fiduciary Administration: Rethinking Popular Representation in Agency Rulemaking, 88 TEX. L. REV. 441, 457-62 (2010) (arguing that the presidential election does not reflect predominantly shared voter preferences on individual agency actions because of numerous disconnects between such actions and the electoral process).

86. See supra notes $74-77$ and accompanying text.

87. Lisa Bressman has justified hard-look review as a means of enforcing the norm against unprincipled agency action. I read Bressman as agreeing with my understanding of hard-look review, which in her words "requires agencies to filter information for ordinary consumption, minimizing informational asymmetries between administrator and legislator." Bressman, Procedures as Politics, supra note 56, at 1780; see also Bressman, supra note 17, Beyond Accountability, at 529 (asserting that reasoned decision-making "may promote accountability by ensuring public participation in or oversight of the administrative process"); $c f$. Eric A. Posner, Controlling Agencies with Cost-Benefit Analysis: A Positive Political Theory Perspective, 68 U. CHI. L. REv. 1137, 1143 (2001) (viewing cost-benefit analysis as performing a similar role). 


\section{Case Law and the Underpinnings of Reasoned Decision-Making}

Watts asserts that the technocratic approach to judicial review, which she finds problematic, is embodied in the Supreme Court cases of State Farm and Massachusetts v. EPA. ${ }^{88}$ Although she is correct that those cases do not invite agencies to proffer political influence as a factor in arbitrary and capricious review, those cases do not support her understanding that courts consider political influences to be illegitimate motivations for rulemaking.

The National Highway Traffic Safety Administration's (NHTSA) regulation of automobile passive restraints-originally requiring the installation of seatbelts or airbags - certainly tracked the politics of who was in the White House. ${ }^{89}$ Yet, as Watts emphasizes, the Court did not consider this factor in evaluating the Reagan administration's decision to abandon requiring passive restraints in automobiles. ${ }^{90}$ According to Watts, the Court focused on the agency's failure to consider whether air bags alone would provide sufficient safety benefits. The Court also questioned NHTSA's dismissal of the safety of automatic seatbelts. ${ }^{91}$ Watts, however, elides direct indications that the Court understood and accepted that politics motivated the decision. ${ }^{92}$

A crucial passage from the State Farm majority, included in Watts's excerpt, explains that an agency must consider all relevant factors and important aspects of a problem. ${ }^{93}$ But that passage also points out that a court will not reverse an agency determination on grounds that it reflects an error of judgment unless the explanation "is so implausible that it could not be ascribed to a difference in view or the product of agency expertise." $"$ The term "difference in view" indicates that the agency is entitled to rely on value judgments as bases for challenged rules. The Court simply does not focus on those directly because, in my opinion, it has no business second guessing them.

88. Watts, supra note 7, at 19, 21-22.

89. See Thomas J. Miles \& Cass R. Sunstein, The Real World of Arbitrariness Review, 75 U. CHI. L. Rev. 761, 770 (2008) (noting that the rule adopted while Carter was president was rescinded within six months of Reagan taking office).

90. Watts, supra note 7 , at 6 .

91. Id. at $17-19$.

92. Id. at 19 .

93. Id. at 17 .

94. Motor Vehicle Mfrs. Ass'n v. State Farm Mut. Auto. Ins. Co., 463 U.S. 29, 43 (1983) (emphasis added). 
One might argue that, by allowing a court to reverse an agency decision that the court believes to be a clear error in judgment, the court imposes an objective rationality requirement on agency value judgments. ${ }^{95}$ After all, if hard-look review leaves agencies free to make value judgments without judicial constraint, how can a court justify rejecting such a judgment? To understand this component of hard-look review, one must first recognize that, unlike the process-based components of such review, courts rarely, if ever, use the clear error in judgment standard to invalidate agency policy choices. ${ }^{96}$ Courts essentially include the clear error standard as part of hard-look review to cover those cases in which the agency's purported value judgment is inconsistent with any value that could reasonably be attributed to the statute. When that is the case, it is almost certain that the rule reflects some unstated rationale, which is unstated either because the agency's authorizing statute precludes its use or because the agency does not want to suffer the political ramification for revealing this justification. For example, adopting a rule that has no justification except to pay back an interest group that strongly supported the president's campaign would be arbitrary, ${ }^{97}$ and the president would not want to reveal that rationale even if it was not. In short, courts allow reversal for clear error of judgment only if the agency explanation is so incredible that it is fairly certainly pretextual, which is consistent with the explanation of hard-look review as being meant to increase the transparency of agency decisions.

Watts also notes that the majority parted ways with Justice Rehnquist, who concurred in the judgment but dissented on the question of whether the agency's prediction about detachable seatbelts was arbitrary and capricious. ${ }^{98}$ She further points out that, although this finding was not a necessary part of his decision, Rehnquist opined that: "A change in administration brought about by the people casting their votes is a perfectly reasonable basis for an executive agency's reappraisal of the costs and benefits of its programs and regulations."

95. See Magill \& Vermeule, supra note 64, at 1054 (asserting that hard-look review was given a "substantive cast ... when the Supreme Court suggested that reviewing courts should ensure not only that agencies consider the relevant factors, but also that agencies have made no "clear error of judgment"').

96. Stephen G. Breyer et Al., Administrative law And Regulatory Policy 366 (4th ed. 1998).

97. See Mendelson, "Political" Oversight, supra note 7, at 1144-45; cf. Watts, supra note 7, at 65 (stating that a congressman's "hardball" threat should not be considered to justify agency decisions).

98. Watts, supra note 7, at 18-19.

99. Id. at 18 (quoting Motor Vehicle Mfrs. Ass'n v. State Farm Mut. Auto. Ins. Co., 463 U.S. 29, 
read too much into the majority's failure to respond to this point, she indicates that scholars have widely read the majority's disagreement with Justice Rehnquist "to represent the triumph of expertise to the exclusion of politics." 100

Reading the State Farm majority's refusal to address politics as an expression of antipathy toward political influence in agency decisionmaking is, as Watts concedes, problematic because the agency itself did not rely on such influence to justify its decision. ${ }^{101}$ In some sense, Rehnquist's statement is off the mark because the agency premised its decision on a prediction that automatic seatbelts would be disabled and hence would provide little benefit. ${ }^{102}$ Having done so, it is incumbent on the agency to analyze this prediction and explain why it is reasonable in light of all factors likely to bear on its accuracy, which the majority believed included the factor of inertia facing occupants who might not want to buckle up. ${ }^{103}$ The prediction of likely usage of automatic seatbelts is an empirical question rather than a value judgment on which politics has any legitimate bearing.

Under my understanding of hard-look review, had the agency wanted to rely on politics to justify its decision, it would have had to identify the policy preferences underlying that reliance. Only by doing so can the agency be held politically accountable for its decision. For example, had NHTSA objectively evaluated the benefits of imposing a passive restraint rule, but declined to impose such a rule based on its valuation of the autonomy of car owners to buy the cars that they prefer, I believe that the majority would have had to accept this valuation as reasonable. ${ }^{104}$ The agency, however, probably would not have relied on this valuation, both because it did not resonate with popular sentiments and because the Court might have held that automobile owner autonomy was outside the factors that the agency's authorizing statute allowed it to consider. ${ }^{105}$ Given the

\footnotetext{
59, 43 (1983) (Rehnquist, J., concurring in part and dissenting in part)).

100. Id. at 19 .

101. Id.

102. See State Farm, 463 U.S. at 47.

103. Id. at 52,54 .

104. See Scalia, Rulemaking as Politics, supra note 32, at xxxi (commenting on the D.C. Circuit's rejection of NHTSA's decision to reverse its passive restraint rule: "[I]t would be refreshing and instructive if . . . [NHTSA had] said flat out: 'It is our judgment that people should not be strapped in cars if they don't want to be; nor should they have to spend substantial sums for air-bags if they choose otherwise."').

105. Given that the National Traffic and Motor Vehicle Safety Act of 1966 authorized regulation of "unreasonable risk," Pub. L. No. 89-563 §102(1), 80 Stat. 718, 718 (codified at 4 U.S.C. $\S 30121(a)(1)(D)$ (2012)), it is not clear whether courts would have found driver autonomy to be outside those factors the statute allowed the agency to consider.
} 
constraints of politics and the statute, the agency tried to hide a political decision behind a misleading technical explanation, and the Court properly rejected this technical obfuscation.

Watts also sees Massachusetts v. EPA as signaling judicial antipathy for political influence on agency decision-making. ${ }^{106}$ In that case, the EPA denied a petition to commence a rulemaking proceeding to regulate greenhouse gas emissions on various grounds, including that regulation under the Clean Air Act would conflict with the Bush Administration's policies and efforts to work out a global approach to climate change. ${ }^{107}$ The Court held that the EPA arguments were not sufficient to justify refusing to regulate because the statute required the agency to determine whether human-generated greenhouse gases contribute to global warming or to explain why it cannot or should not make that determination. ${ }^{108}$

The Massachusetts v. EPA majority did refuse to credit the EPA's arguments that there were political reasons why it decided not to regulate greenhouse gas emissions. Thus, the Court's decision seems to dismiss political explanations in this case as illegitimate. This is surprising, especially given that the Court was reviewing a decision not to commence rulemaking. Under the deferential standard of review that courts often apply to such decisions, statements that the agency prefers to devote its rulemaking resources to other regulatory endeavors usually pass judicial muster. ${ }^{109}$ Thus, Watts is not alone in seeing the majority's opinion as rejecting arguments that the agency may be influenced by politics in a context where that influence does not seem problematic. ${ }^{110}$ But, one can read Massachusetts v. EPA as supporting my view of the role of politics as well. The Court did not claim that politics was irrelevant to how the agency chose to regulate, but it read the Clean Air Act as predicating

106. Watts, supra note 7, at 21-22.

107. Massachusetts v. EPA, 549 U.S. 497, 511-14 (2007) (summarizing EPA denial of rulemaking petition)

108. Id. at 533 .

109. In Massachusetts v. EPA, however, the agency had already committed to seeking notice and comments and did not rely on its discretion to invest its regulatory resources where it thought they could do the most good. Id. at 511-13. Under established circuit court precedent, courts review such denials of rulemaking petitions under the usual hard-look standards, but arguably, in such situations, they are less apt to hold that an agency acted arbitrarily and capriciously for failing to collect data and perform analyses it would need to determine the extent to which regulation was justified. See, e.g., Prof'l Pilots Fed'n v. FAA, 118 F.3d 758, 764, 769-70 (D.C. Cir. 1997) (claiming to apply the hardlook doctrine because the agency refusal to initiate a rulemaking was on the merits, but tolerating the agency refusal to create opportunities to generate data to see if the rule was sensible).

110. See, e.g., Freeman \& Vermeule, supra note 9, at 52 (reading Massachusetts as creating a doctrine of expertise-forcing "to ensure that agencies exercise expert judgment free from outside political pressures"). 
whether to regulate at all on scientific determinations. ${ }^{111}$ Hence, by the majority's view, it was Congress that rejected the political factors that the agency relied on to justify its decision, not the Court invoking the hardlook test.

Finally, Watts is encouraged by the recent decision in Fox Television, in which the majority upheld a change in FCC rules that prohibited a television station from broadcasting fleeting expletives even if used other than in their sexual or scatological sense. ${ }^{112}$ The central holding of the Fox Television majority is that an agency need not satisfy a stiffer standard when it changes a policy than when it adopts a policy in the first place. ${ }^{113}$ In Fox Television, Watts sees an easing of the burden on agencies to justify changes in policy that may reflect political decisions. ${ }^{114}$ She finds especially encouraging that Justice Scalia, in part of the opinion joined by three other justices, "frankly acknowledged [that the change in policy] was 'spurred by significant political pressure from Congress.", 115

But, as I explained previously, recognizing the legitimacy of political pressure on rulemaking is not a change from traditional hard-look review. Scalia's opinion never relied on political pressure as a basis for reducing the stringency of the judicial inquiry into the reasons the agency gave for its action. In fact, his recognition of the political pressure was in rebuttal to Justice Stevens's dissent, which argued that independent agencies were meant to be responsive to Congress, not just the president. ${ }^{116}$ Scalia cited political pressure only to note that the FCC was in fact responding to the desires of members of Congress. ${ }^{117} \mathrm{He}$ intimated that Stevens could not have it both ways - contending that agencies were to respond to Congress but could not take congressional pressure into account when setting policy. ${ }^{118}$ Thus, if there is anything to celebrate in Scalia's Fox Television opinion, it is the clarification that political influence is appropriate in the

111. Massachusetts v. EPA, 549 U.S. at 533-34.

112. FCC v. Fox Television Stations, Inc., 556 U.S. 502, 517-18 (2009).

113. Id. at 514 .

114. Watts, supra note 7, at 22.

115. Id. (quoting Fox Television, 556 U.S. at 523).

116. Fox Television, 556 U.S. at 539-41 (Stevens, J., dissenting) (arguing that the FCC, as an independent agency, is an agent of Congress and not the president and, as such, is particularly bound by its statutory mandate).

117. Id. at 523 .

118. Id. at 524-25 ("Justice Stevens' conclusion does not follow from his premise. If the FCC is indeed an agency of Congress, it would seem an adequate explanation of its change of position that Congress made clear its wishes for stricter enforcement ...."). 
face of arguable suggestions by Justices Breyer and Stevens to the contrary. ${ }^{119}$

Even this understanding of the Fox Television opinions is questionable, however, because a careful reading of Justice Breyer's dissent indicates that he was not advocating that agency decisions be apolitical. The impression that Breyer's opinion holds that political pressure is not a legitimate motivation for agency decisions is created by his unfortunate phrasing of his description of "applicable law," which states: "[The law] does not permit [agencies] to make policy choices for purely political reasons nor to rest them primarily upon unexplained policy preferences." ${ }^{120}$ But, later in the opinion, he clarifies that he does not mean that agency decisions must be free from politics. He writes:

I recognize that sometimes the ultimate explanation for a change may have to be, "We now weigh the relevant considerations differently." But at other times, an agency can and should say more. Where, for example, the agency rested its previous policy on particular factual findings or where an agency rested its prior policy on its view of the governing law, or where an agency rested its previous policy on, say, a special need to coordinate with another agency, one would normally expect the agency to focus upon those earlier views of fact, of law, or of policy and explain why they are no longer controlling. ${ }^{121}$

In essence, Breyer's dissent in Fox Television explains that agencies may rely on changes in value judgments, and presumably these may be prompted by political changes. But, an agency must explain those policy choices by establishing the underlying factual and legal predicates to its action so that it can be held accountable for the value choices it makes.

While Watts focuses on the few Supreme Court cases applying arbitrary and capricious review, lower court cases provide clear indications that although courts do not entertain invocations of political pressure under such review, they fully accept that agencies frequently are driven by political pressure. ${ }^{122}$ Perhaps no case illustrates this nuanced conception of

119. See id. at 540 (Stevens, J., dissenting) (expressing the view that independent agencies are "established "to carry into effect legislative policies embodied in the[ir] [enabling] statute" (quoting Humphrey's Ex'r v. United States, 295 U.S. 602, 628 (1935))); Fox Television, 556 U.S. at 547 (Breyer, J., dissenting) (stating that the law does not allow independent agencies to set policy for "purely political reasons").

120. Id. at 547.

121. Id. at 550-51 (citations omitted).

122. See infra notes $123-47$ and accompanying text. 
the role of politics better than Sierra Club v. Costle. ${ }^{123}$ In that case, the D.C. Circuit considered EPA rules implementing the 1977 amendments to the Clean Air Act's new source performance standards provisions. ${ }^{124}$ These amendments reflected efforts by competing coalitions of environmentalists, power plant owners, and eastern coal interests to try to influence the standard the EPA ultimately would have to adopt. ${ }^{125}$ The statute was far from determinative about which interests would win out. ${ }^{126}$

The agency adopted a standard that resulted in dirtier air at greater cost than an alternative it had considered because the adopted standard provided greater protections to eastern coal interests. ${ }^{127}$ Senator Robert Byrd, from the coal-producing state of West Virginia actively met with the agency and seemed to have persuaded the White House to get involved in the rulemaking proceeding to support his preferred standard, which was ultimately adopted. ${ }^{128}$ Despite the perversity of the effects of the standard, the politics behind it, and the scores of pages the court wrote on technical questions about the agency decision as part of its hard-look review, ${ }^{129}$ the court affirmed the agency ultimately because its analysis clearly showed that the adopted standard helped protect eastern coal producers. The court noted that encouraging use of local coal was one of numerous purposes of the statute. ${ }^{130}$ In response to objections about meetings with the president that the EPA had not docketed, Judge Wald wrote for the court:

Of course, it is always possible that undisclosed Presidential prodding may direct an outcome that is factually based on the record, but different from the outcome that would have [been] obtained in the absence of Presidential involvement. In such a case, it would be true that the political process did affect the outcome in a way the courts could not police. But we do not believe that Congress intended that the courts convert informal rulemaking into

123. 657 F.2d 298 (D.C. Cir. 1981).

124. Id. at 316.

125. Bruce A. Ackerman \& William T. Hassler, Clean Coal/Dirty Air: Or How the Clean Air Act Became a Multibillion-Dollar Bail-Out For High-Sulfur Coal Producers AND What Should Be Done ABout IT 29-33 (1981).

126. Id. at 107 .

127. Id. at $33-35$.

128. Id. at $100-02$.

129. See Sierra Club, 657 F.2d at 318-84 (applying hard-look review to the technical issues raised by the EPA adoption of the standard). The court's review was so extensive, it prompted Judge Wald to write: "We reach our decision after interminable record searching (and considerable soul searching). We have read the record with as hard a look as mortal judges can probably give its thousands of pages." Id. at 410 .

130. Id. at 339-40. 
a rarified technocratic process, unaffected by political considerations or the presence of Presidential power. ${ }^{131}$

In response to objections of undue congressional influence on the agency decision, Judge Wald stated:

D.C. [Circuit precedent] requires that two conditions be met before an administrative rulemaking may be overturned simply on the grounds of Congressional pressure. First, the content of the pressure upon the Secretary is designed to force him to decide upon factors not made relevant by Congress in the applicable statute. . . . Second, the Secretary's determination must be affected by those extraneous considerations. ${ }^{132}$

What is telling about these quotes is the clarity with which they distinguish between the influences to which agencies might respond and what the courts can actually police. This oft-cited case on hard-look review manifests that although political influence is not relevant to such review, it is a normal — even desirable — input into agency rulemaking. ${ }^{133}$

The Three Sisters Bridge case, ${ }^{134}$ although it involves informal adjudication rather than rulemaking, provides a factual scenario that illuminates the differences between my understanding of hard-look review and a review that would credit agencies' reliance on politics to justify their actions. The case involved a proposed bridge that would have provided an interstate highway connection between Virginia and the waterfront of Georgetown in Washington, D.C. ${ }^{135}$ The project required the approval of

131. Id. at 408 .

132. Id. at 409 .

133. Watts acknowledges that Sierra Club embraces the political influence of agency rulemaking. Watts, supra note 7, at 38. Apparently, however, she sees this embrace as occurring only in the context of the law of ex parte contacts because she ignores the scores of pages Judge Wald's opinion devotes to technically focused hard-look review of the EPA rule. See id. at 39. The natural implication of Watts's reading of this case is that Judge Wald recognized the importance of political influence when evaluating communication between the agency and the president and members of Congress in a rulemaking proceeding but considered that same influence illegitimate when evaluating the substance of the rule. To me, this description of how judges decide cases strains credibility. As my description of the Sierra Club holding illustrates, I believe that Judge Wald embraced the importance of political influence with respect both to the necessity of communications between the agency and its political principals and to the desirability of informing the agency's ultimate value judgments. She did not, however, rely on political influence to conclude that the agency decisions were justified. See generally Sierra Club, 657 F.2d 298.

134. D.C. Fed'n of Civic Ass'ns v. Volpe (Three Sisters Bridge case), 459 F.2d 1231 (D.C. Cir. 1971).

135. Id. at 1236 . 
the District of Columbia Council and the Secretary of Transportation. ${ }^{136}$ Because the bridge would have used parkland, the Secretary had to find that there was no feasible alternative to the bridge to move traffic between Virginia and Georgetown. ${ }^{137}$ In making this finding, the Secretary was to weigh the value of parkland heavily. ${ }^{138}$

Congressman Natcher, the chairman of the Subcommittee on the District of Columbia of the House of Representatives, was a strong advocate for the bridge. ${ }^{139}$ He threatened that Congress would withhold funding for construction of the District's subway system if the Council did not approve the bridge. ${ }^{140}$ Although a majority of the Council voted to approve the bridge project, several swing voters protested vociferously that they voted to approve the measure only because of Representative Natcher's threat. ${ }^{141}$ Secretary of Transportation Volpe, apparently recognizing the support of key members of Congress for the bridge, rushed the project through the approval process. ${ }^{142}$

The D.C. Circuit reversed Volpe's approval of the project, finding that the record did not support the government's contention that the Secretary had followed all the statutorily required procedures and considered alternatives that involved not building any bridge. ${ }^{143}$ In this sense, the case was easy. Judge Bazelon, however, also indicated that, for him, the impact of Representative Natcher's threat by itself justified the reversal of the Secretary's approval. ${ }^{144}$ This raises the question whether the court should have reversed the approval if Volpe had followed the required procedures and considered the alternatives.

Under my approach, the District Council's response to the threat regarding the withholding of subway funds constituted a justification that

136. $I d$.

137. Id.

138. See Citizens to Preserve Overton Park v. Volpe, 401 U.S. 402, 411-13.

139. Three Sisters Bridge case, 459 F.2d at 1236, 1245-46.

140. Id.

141. Id. at $1236,1245$.

142. Id. Volpe, citing congressional authorization of funding for the bridge, initially approved the bridge without even sending it through the statutorily required process. Id. at 1237-39. The determination that Congress had excepted the bridge from this process was reversed in an earlier decision in the case. D.C. Fed'n of Civic Ass'ns, Inc. v. Volpe, 434 F.2d 436, 436, $445-47$ (D.C. Cir. 1970).

143. Three Sisters Bridge case, 459 F.2d at 1237-40.

144. Id. at 1245. The other judges on the panel did not join this part of Judge Bazelon's opinion. See id. at 1246 (noting that Judge Fahy did not find a need to address this issue); id. at 1256-57 (MacKinnon, J., dissenting in part) (explaining that he was not convinced that Representative Natcher's pressure had changed the Secretary's evaluation of the project). 
was not relevant to the approval of the bridge. ${ }^{145}$ The threat was irrelevant not because it was political, but rather because the subway funding had no logical relation to the bridge-it was simply an attempt to leverage political power. Under the hard-look doctrine, the court would have been justified in reversing the approval. Watts indicates that she too would find invocation of the threat insufficient to justify approval of the bridge, ${ }^{146}$ although it is not clear why given that Representative Natcher's threat was hardly unusual in the push and pull of politics. ${ }^{147}$

A starker contrast between my approach and that of Watts is presented by considering another variation on the facts of the Three Sisters Bridge case. Suppose first that Representative Natcher's subcommittee publicly expressed strong desire for the bridge in an official subcommittee report, but said nothing about funds for the subway. Suppose further, however, that the Secretary understood that Natcher could deliver votes to kill funding for the subway if the bridge was not approved. Finally, postulate that the Secretary had met the technical procedural and consideration requirements of the statute but had justified the impact on parkland by invoking Congress's political support for the bridge. Although such political influence is clearly legitimate, as I understand hard-look review, the court should nonetheless reverse the Secretary's determination for failing to explain why the benefits of building the bridge outweighed the loss of parkland. ${ }^{148}$ In contrast, if Watts's proposal has any teeth at all, it would demand that the reviewing court uphold the approval based on the subcommittee's expression of support for the bridge.

\section{THE NoRmative CASE AgAINST POLITICS IN ARBITRARY AND CAPRICIOUS REVIEW}

In part, Professor Watts's characterization of reasoned decision-making as antagonistic to political influence on rulemaking leads her to claim that allowing agencies to rely explicitly on politics to justify their regulatory

\footnotetext{
145. See Sierra Club v. Costle, 657 F.2d 298, 409 (opining that the threat to withhold subway funds in the Three Sisters Bridge case was not among the factors relevant to the determination of whether the bridge in that case should be built).

146. See Watts, supra note 7, at 65 .

147. The threat was not only unusual, it was extremely credible. Representative Natcher's subcommittee had gotten Congress to withhold funds for the subway and released those funds only after the Council voted to approve the bridge. Three Sisters Bridge case, 459 F.2d at 1245.

148. To clarify my understanding, had Secretary Volpe explained why the bridge was warranted despite its use of parkland without invoking his reading of Congress's preference, the court would be justified in affirming the approval despite the political motivation for the Secretary's decision. See supra notes 35-37 and accompanying text.
} 
decisions would change arbitrary and capricious review for the better. ${ }^{149}$ She describes the benefits of her proposal as making agency decisions more honest and keeping courts in check. ${ }^{150}$ Most significantly, she argues that allowing agencies to invoke politics will reveal the true basis of many agency decisions, which will make agencies' decisions more accountable. ${ }^{151}$ Additionally, she contends that allowing agencies to rely on political preferences of the administration will relieve agencies from pressure to manipulate science to justify their decisions, thereby encouraging agencies to be more honest about the science behind their decisions. ${ }^{152}$ As a third point, Watts concludes that her proposal would decrease the ossification of rulemaking because agencies will not have to spend time and resources on factual and scientific determinations that do not influence their decisions. ${ }^{153}$ A proper understanding of the role of hard-look review in the administrative process, however, suggests that Watts's normative assessment on all three points is problematic.

\section{A. Transparency and Political Accountability for Regulations}

Essentially, Watts's proposal would allow agencies to substitute the invocation of political preferences for at least some development of facts and reasoning about impacts of agency regulations. Although Watts never explicitly addresses how political factors should be balanced alongside technical ones, ${ }^{154}$ she indicates that invocation of politics, in some instances, should allow an agency rule to pass hard-look review that would not pass as courts currently apply that standard. ${ }^{155}$ Also, as she would incorporate politics into judicial review, politics would never disqualify a regulation that otherwise would meet the hard-look standard. ${ }^{156}$ By

149. Watts, supra note 7, at 16-20, 32-33, 84 .

150. Id. at 33-34.

151. Id. at 42-45. Although this is the last argument Watts presents, she labels it as perhaps the most important one. Id. at 42.

152. Id. at $41-42$.

153. Id. at $42-45$.

154. Id. at $72-73$

155. See id. at 73.

156. Id. at 76 (noting that, under her proposal, agencies would get additional deference for revealing political reasons, but would pay no price for not invoking them). Because agencies would not have to reveal political influence on which they did not rely to justify a rule, Watts's proposal would allow them to conceal improper political influence. Id. Watts recognizes this problem, and therefore expresses some willingness to allow courts to reverse agencies for failure to reveal political influence on which he rule was based. Id. at 76-77. She points out, however, that a requirement that courts require agencies to reveal political communications is fraught with constitutional difficulties and problems of judicial competence. Id. at 76 . 
implication, political considerations would substitute for the missing analysis that would render a decision arbitrary and capricious under the current invocation of the standard.

The idea behind Watts's proposal is that the electorate will evaluate whether it agrees with the political decision. That public evaluation will constrain the president from encouraging the agency to act in a manner that is not politically supported. By her account, hard-look review hinders the openness of political influence on agency regulation. ${ }^{157}$ As I argued above, however, hard-look review does not condemn political influence. It merely recognizes that presidential and congressional influences often do not reflect political support for the precise trade-offs that an agency regulation entails. Contrary to Watts's contentions, allowing an agency to fall back on general recitation of presidential support for a rule permits the agency to hide the details of the value judgments it makes. Generally, political support for a policy is not all-or-nothing. There may be political support for a policy similar to the one the agency adopts, yet that support may depend on how far the agency takes that policy - that is, on the tradeoffs that stakeholders will have to make if the agency acts as the president desires. Under my conception of hard-look review, the agency has to develop a record that will indicate and support its best assessment of the impact of its policy in terms of benefits bestowed and costs engendered.

The case of Rust $v$. Sullivan ${ }^{158}$ provides an illuminating example of how Watts's proposal allows an agency to escape from having to reveal the true nature of its value judgments. Rust involved the Secretary of Health and Human Services (HHS) in the Reagan Administration changing an interpretation of the meaning of a provision in Title $\mathrm{X}$ of the Public Health Service Act, which prohibits federal money made available under that Title from "be[ing] used in programs where abortion is a method of family planning." 159 The new interpretation prohibited recipients of Title X funds-including doctors - from counseling women about abortion. ${ }^{160}$ The case generated a heated debate among the justices about the First Amendment in the context of government-funded activity, ${ }^{161}$ but I want to focus on the administrative law question of whether the agency rule was consistent with the Act. ${ }^{162}$

157. Id. at 23-26.

158. 500 U.S. 173 (1991)

159. Id. at 177-79 (quoting Public Health Services Act, 42 U.S.C. $\S 300 a-6$ (1970)).

160. Id. at $179-80$.

161. Id. at 192-205, 208-20, 224-25.

162. See id. at 183 . 
The Court applied Chevron and held at step one that the statute was ambiguous about the precise meaning of programs where abortion is a method of family planning. ${ }^{163}$ The Court explicitly concluded that the statute was silent about whether recipients of Title X funds can engage in counseling about abortion, but that the agency's interpretation was clearly within bounds allowed by the statute. ${ }^{164}$ With respect to step two of Chevron, comments in the rulemaking indicated that even though the rule applied only to abortion as family planning, the agency interpretation was problematic because it would prohibit doctors in family planning clinics from informing women for whom childbirth might pose a significant risk to their lives and health about abortion as an option. ${ }^{165}$ Comments also expressed concern that the new interpretation might keep women who ultimately choose abortion from doing so in a timely manner, thereby exposing them to later term procedures that pose greater risks to their health. ${ }^{166}$ The comments noted that many women who use family planning clinics do not have personal physicians who would otherwise inform them of the abortion option. ${ }^{167}$ The agency never assessed the effect of its rule on risks to the health of Title X clients, ${ }^{168}$ but merely opined that there is an adequate basis for the rule because it is reasonable under all circumstances. ${ }^{169}$ The Court held that the agency had adequately justified its changed interpretation as necessary to prevent abuses and the

163. Id. at 184 .

164. Id.

165. See Statutory Prohibition on Use of Appropriated Funds in Programs Where Abortion is a Method of Family Planning, 53 Fed. Reg. 2922, 2929 (Feb. 2, 1988) [hereinafter Abortion Counseling Regulations] (reporting comments expressing concern that the rule "would require physicians to remain silent when confronted with a pregnant patient with medical conditions which may be exacerbated by pregnancy, such as diabetes, multiple sclerosis, lupus, or AIDS"); see also id. at 2932 (essentially admitting that the rule would preclude communication about abortion to a patient for whom childbirth might pose a threat to life or health by stating that precluding the doctor from discussing abortion in such a situation would not violate medical ethics).

166. See id. at 2936 (summarizing such comments); Id. at 2938 (responding that such delay has the beneficial effect of "allow[ing] sufficient time for reflection prior to making an informed decision" and, in any case, is consistent with the statute, which clearly intended that abortion not be facilitated through the Title X program).

167. See id. at 2925 (indicating that some family planning providers argued that "for many Title $X$ clients, the Title X project constitutes their only source of health care").

168. The drafters did change the rule to include what some might term an exception-obligating Title X providers to provide clients with immediate referrals to appropriate medical facilities when confronted with immediately life-threatening emergencies, such as ectopic pregnancies. Id. at 2937.

169. Id. at 2925 (citing Chevron). In doing so, the agency confuses Chevron's instruction to reviewing courts with the standard an agency should meet in interpreting a statute. See Mark Seidenfeld, A Syncopated Chevron: Emphasizing Reasoned Decisionmaking in Reviewing Agency Interpretations of Statutes, 73 TEX. L. REV. 83, 111 \& n.157 (1994) [hereinafter Seidenfeld, A Syncopated Chevron]. 
appearance that funds were being used to support abortion. ${ }^{170}$ Most relevant to this article, the agency explained that the new interpretation was "supported by a shift in attitude against the "elimination of unborn children by abortion." "171

Essentially in Rust, under step two of Chevron, the Court did precisely what Watts advocates under the arbitrary and capricious standard of review. And, at first blush, this seems like the quintessential case that justifies the invocation of the political values of the administration. Abortion is a contentious political issue that has played a significant role in presidential campaigns. ${ }^{172}$ President Reagan announced the decision and made his support of it clear, implying that the White House was essentially the driving force behind the rule change. ${ }^{173}$ Reagan's announcement came at a time when Vice President George H.W. Bush was facing a challenge from the Right for the Republican nomination in the next presidential election. ${ }^{174}$ Presumably, those in favor of restricting access to abortions would see the Secretary's interpretation as a reason to vote for Bush in the next election, and those opposed would use it as a reason to vote against him.

But, for many people the issue is not simply being for or against abortion. Whether the abortion is necessary to protect the life and health of the pregnant woman affect many people's idea of whether abortion is justified in particular instances. ${ }^{175}$ By invoking the president's political preference, however, HHS was able to avoid having to indicate the effect of its changed interpretation on pregnant women whose health might be

170. Rust v. Sullivan, 500 U.S. at 187.

171. Id. (quoting Abortion Counseling Regulations, supra note 165, at 2944).

172. News articles reporting on abortion as a campaign issue are legion. See, e.g., Marc Santora, Giuliani Tries to Reassure Religious Conservatives, N.Y. TIMES, Oct. 4, 2007, at A23; Richard L. Berke, Christian Right Issues a Threat to the G.O.P., N.Y. TIMES, Feb. 11, 1995, at 1. The history of the Abortion Counseling Regulations themselves illustrates how the abortion issue can relate to candidates' presidential campaigns. "President Reagan announced that [HHS] would publish proposed [Abortion Counseling] [R]egulations" on July 30, 1987. Abortion Counseling Regulations, supra note 165, at 2922. This occurred, perhaps not coincidentally, just as Vice President Bush faced opposition from the religious right for the Republican nomination for president. See David E. Rosenbaum, Robertson Backers Eager for Southern Test, N.Y. TIMES, Feb. 13, 1988, at 1; Phil Gailey, Religious Right Challenging G.O.P., N.Y. TIMES, June 2, 1986, at B12.

173. See Abortion Counseling Regulations, supra note 165, at 2922; Spencer Rich, Reagan to Tighten Family-Planning Aid Rules, WASH. POST, July 30, 1987, at A9.

174. See Seidenfeld, A Syncopated Chevron, supra note 169, at 101-02.

175. Abortion, GALLUP, http://www.gallup.com/poll/1576/abortion.aspx\#2 (last visited Oct. 12, 2011). In 2011, when survey respondents were asked directly whether abortion should be legal or illegal when the woman's life is in danger, 83 percent believed it should be legal and 13 percent believed it should be illegal. This is in stark contrast to 47 percent of Americans who identify as prolife. Id. 
endangered by childbirth, many of whom did not have personal physicians to inform them of the related risks. ${ }^{176} \mathrm{I}$ do not doubt that the Reagan administration could have justified its ultimate interpretation of Title X. But, it is not certain that the Secretary of HHS would have adopted that interpretation or that the interpretation would have had the same political impact if the Secretary had to explain that for whatever number of fetuses HHS expected the policy to keep from being aborted, it would also likely result in the death of a certain number of women.

A second problem with the accountability defense of Watts's proposal is its extreme optimism about the capability of the political market to register preferences about regulatory outcomes. Watts argues that her proposal would bring the arbitrary and capricious review in line with the widely accepted model of political control as a justification for the administrative state. ${ }^{177}$ The implications of that model for judicial doctrine, however, are more complicated than Watts's analysis suggests. In particular, her argument that hard-look review is inconsistent with the political control model assumes that such control will sufficiently constrain agency regulation so that it reflects the values of the polity. ${ }^{178}$

The political control model focuses on Congress and the president as providing accountability for agency decisions. ${ }^{179}$ Outside the formal mechanisms of legislation and Senate votes on presidential appointments, congressional influence operates primarily through the committee system. ${ }^{180}$ There are serious problems both with ascribing the influence wielded in committees to the legislature as a whole ${ }^{181}$ and with the ability

176. See supra notes 166-67 and accompanying text.

177. Watts, supra note 7, at 39.

178. See Criddle, supra note 85, at 461 (describing "the [f]iction of [p]residential [a]ccountability"); Glen Staszewski, Reason-Giving and Accountability, 93 MiNN. L. REV. 1253, 1266-71 (2009); Heidi Kitrosser, The Acccountable Executive, 93 MinN. L. REV. 1741, 1763-69 (2009) (noting that the President's control over information allows him to escape meaningful accountability for agency policies); Peter M. Shane, Political Accountability in a System of Checks and Balances: The Case of Presidential Review of Rulemaking, 48 ARK. L. REV. 161, 197-202 (1995) (critically analyzing the assertion that presidential management of administrative policy is accountable to public opinion).

179. See Watts, supra note 7, at 35-36 (noting that the political control model legitimates agency political decision-making by stressing that agencies are accountable because they are controlled by the political branches).

180. See Jack M. Beermann, Congressional Administration, 43 SAN DIEGo L. REV. 61, 70 (2006) (discussing the role of committees in the informal supervision of agencies).

181. Neither the fact that legislative committees are not necessarily representative of the legislature as an institution, nor the lack of the accountability of individual members of Congress to any national constituency renders the influence of committee members on agencies illegitimate in the rough and tumble of interactions among the political branches. See FCC v. Fox Television, 556 U.S. 502, 525 n.5 (2009) (indicating that "extrastatutory influence Congress exerts over agencies . . by the 
of elections within individual congressional districts to hold committee members accountable to the general national interest. ${ }^{182}$ The president, however, is more promising as a source of public-interest-focused influence. After all, the president answers to the entire electorate, so he has an incentive to regulate only when the regulation benefits the nation as a whole. ${ }^{183}$ Unfortunately, the system of electing the president does not operate so efficiently that one can trust the president to influence agencies to act in the public interest on most, let alone all, regulatory issues. ${ }^{184}$

Problems with presidential control are illuminated by the public choice critique of the interest group model, which highlights ways in which focused interest groups have an advantage in the political arena over diffuse interest groups. ${ }^{185}$ On many issues, the general public will not have any knowledge that an agency acted. They will have even less knowledge about how the agency acted. And, they will almost certainly not have any idea about the impacts or even the significance of the action. ${ }^{186}$ Those directly subject to regulation are likely to be aware of all the implications of a potential new rule. ${ }^{187}$ Hence, they are more apt to seek White House

congressional committees responsible for oversight and appropriations with respect to the relevant agency" is proper). Permitting courts to distinguish regulations they will affirm from those they will reverse based on the expressed views of a subgroup of the legislature, however, would seem to run afoul of the constitutional principle that Congress cannot delegate its lawmaking powers to a subgroup or agent of the legislative branch. According to John Manning:

The constitutionally ordained legislative process of bicameralism and presentment is designed to check factional influence, promote caution and deliberation, and provoke public discussion.

To prevent the circumvention of that process, the Court has consistently forbidden Congress to reserve delegated authority for its own components, agents, or members.

John F. Manning, What Divides Textualists from Purposivists?, 106 Colum. L. REv. 70, 84 n.52 (2006) (citation omitted) (citing as examples supporting his statement, Metro. Wash. Airports Auth. v. Citizens for the Abatement of Aircraft Noise, Inc., 501 U.S. 252, 275-77 (1991); Bowsher v. Synar, 478 U.S. 714, 726 (1986); INS v. Chadha, 462 U.S. 919, 944-59 (1983)).

182. See William N. ESKRIDGE, PHILliP P. FrickEy \& ElizABETH GARRETT, LEGISLATION AND STATUTORY INTERPRETATION 71 (2000) (describing the committee system as a means of delivering unjustified benefits to special interest groups); Barry R. Weingast \& William J. Marshall, The Industrial Organization of Congress; or, Why Legislatures, Like Firms, Are Not Organized as Markets, 96 J. POL. ECON. 132, 157-58 (1988) (describing the committee system as a mechanism to facilitate legislators obtaining benefits that may run counter to the preferences of the majority of the legislative body).

183. See Mashaw, supra note 19 , at $95-96$

184. See Criddle, supra note 85, at 461-64; Shane, supra note 178, at 204-06.

185. See Steven P. Croley, Theories of Regulation: Incorporating the Administrative Process, 98 COLUM. L. REv. 1, 33-41, 60 (1998).

186. See John A. Ferejohn, Information and the Electoral Process, in INFORMATION AND Democratic Processes 3, 3 (John A. Ferejohn \& James H. Kuklinski eds., 1990) ("Decades of behavioral research have shown that most people know little about . . the public issues that occupy officials from Washington to city hall."); Sally Katzen, Governing in the Information Age: Technology as a Tool of Democratic Engagement, 32 CARDOZO L. REV. 2285, 2288 (2011).

187. In fact, the agency usually will seek out information from regulated industries well before 
support for their preferred regulatory outcomes than would the general public or a group with diffuse interests. In some instances, interest group entrepreneurs might manage to overcome organizational barriers faced by diffuse interest groups. ${ }^{188}$ But even if such entrepreneurs manage to form a public interest group that participates in the rulemaking, they will have a difficult time mobilizing its members to respond to agency action at the polls. ${ }^{189}$

In short, focused interest groups are more likely to have the incentives and ability to monitor agencies and appeal to the White House to support their regulatory preferences. As public choice literature recognizes, the differences in the incentives and costs faced by different interest groups greatly increase the likelihood that regulation will serve special interests at the expense of the general public. ${ }^{190}$ And "neither the contemporary process of presidential selection nor the observed behavior of voters, candidates, or Presidents corroborates the story of a 'Representative-inChief,' whose immunity from regionalism and special interest politics enables him, uniquely, to identify and further some higher will of the whole nation." 191 Therefore, if we seek to improve administrative accountability, it seems worthwhile to maintain nonpolitical checks that at least encourage agencies to reveal the value choices they make when they regulate. Watts's proposal, unfortunately, would compromise one of the

developing a proposed rule. See Wendy Wagner, Katherine Barnes \& Lisa Peters, Rulemaking in the Shade: An Empirical Study of EPA's Air Toxic Emission Standards, 63 ADMIN. L. REV. 99, 127 (2011) (reporting empirical evidence that regulated entities are more aware and involved in rule development than are public interest groups); Cary Coglianese, Challenging the Rules: Litigation and Bargaining in the Administrative Process 38-39 (1994) (unpublished Ph.D. dissertation, University of Michigan) (on file with author) (quoting an EPA official who emphasized the agency interest in getting industry involved in rulemaking at the earliest stage).

188. See Russell Hardin, Collective Action 16-37 (1982) (describing the barriers to collective action and the significance of "political entrepreneurs" in group coordination); JACK L. Walker Jr., Mobilizing Interest Groups in America: Patrons, Professions, and Social MOVEMENTS 41-55 (1991) (describing the role of policy entrepreneurs in mobilizing a large number of people on questions of policy); Robert H. Salisbury, An Exchange Theory of Interest Groups, 13 MIDWEST J. POL. SCI. 1, 11-15 (1969) (explaining how "entrepreneurs/organizers" invest the initial capital needed to overcome barriers to collective action).

189. See Erin A. O'Hara \& Larry E. Ribstein, From Politics to Efficiency in Choice of Law, 67 U. CHI. L. REV. 1151, 1157 (2000) ("The winning interest groups are typically those who can organize most cheaply and effectively to raise and spend money, or to mobilize votes and other political resources.").

190. See George J. Stigler, The Theory of Economic Regulation, 2 Bell J. ECON. \& MGMT. SCI. 3, 3 (1971) (proposing a public choice model arguing that "regulation is acquired by the industry and is designed and operated primarily for its benefit"). See generally MANCUR OLSON, JR., THE LOGIC OF COLLECTIVE ACTION: PUBliC GOODS AND THE THEORY OF GROUPS (1971) (describing organizational advantages of small focused interest groups over large diffuse ones).

191. Cynthia R. Farina, False Comfort and Impossible Promises: Uncertainty, Information Overload, and the Unitary Executive, 12 U. PA. J. CONST. L. 357, 360 (2010). 
most important of such checks-meaningful judicial inquiry into explanations for agency action.

Hard-look review helps ferret out rules that reflect political payoffs rather than electoral support. It does so by demanding that the agency make clear the implications of any agency action. ${ }^{192}$ Not infrequently, agencies are unwilling to do so, perhaps because that will make obvious the costs of the action to the general public and thereby cause political backlash. Instead, they try to couch decisions motivated by political giveaways as benefitting the general public. ${ }^{193}$ In some cases, however, they are unable to do so, and the courts, under the hard-look test, find the agency decision simply illogical or so full of holes in data or reasoning that they reverse the decision. ${ }^{194}$

At first blush, one might think this is the perfect situation for Professor Watts's proposal to provide benefits of transparency. Implicit in her account is the assumption that if the agency is allowed to justify its rulemaking decision on political grounds, then it will have to reveal that its politics is motivated by its desire to provide rents to the special interest group. But that is not how politics works. ${ }^{195}$ Far more likely, the administration would couch its decision as being based on opposition to intrusive and needless government regulation, or some similar political platitude. Unless courts are willing to look behind the spin put on a political statement supporting an agency action, allowing the agency to

192. See supra note 87 and accompanying text.

193. By some accounts, the new source performance standards set by the EPA for coal fired power plants in 1978 were a giveaway to eastern coal producers to placate Senate Majority Leader Robert Byrd. See Bruce A. Ackerman \& William T. Hassler, Beyond the New Deal: Coal and Clean Air Act, 89 YALE L.J. 1466, 1552-53 (1980); see also Christopher S. Yoo, The Rise and Demise of the Technology-Specific Approach to the First Amendment, 91 GEO. L.J. 245, 352-53 (2003) (describing the FCC giveaway of spectrum to television broadcasters for the development of high definition television as an illustration of public choice theory in operation).

194. See, e.g., Owner-Operator Indep. Drivers Ass'n v. Fed. Motor Carrier Safety Admin., 494 F.3d 188, 197-98, 206 (D.C. Cir. 2007) (finding the Federal Motor Carrier Safety Administration's hours-of-service regulations for long-haul truckers to be arbitrary and capricious because of numerous questionable steps in its analysis and computer modeling of the effects of driver fatigue on the likelihood of truck crashes); see also Tummino v. Torti, 603 F. Supp. 2d 519, 544-47, 549-50 (E.D.N.Y. 2009) (finding that the agency's factual record clearly indicated that emergency contraceptive Plan B was safe and effective for women over 16 years of age and that politics had influenced the agency to rely on improper factors in declining to approve an over-the-counter version of that contraceptive for women 17 and older).

195. See Tamara R. Piety, Against Freedom of Commercial Expression, 29 CARDOZO L. ReV. 2583, 2662-63 (2008) (describing how politicians use "techniques of advertising and promotion" and arguing that they are corrosive to democracy); Roger A. Pielke, Jr., Policy, Politics and Perspective: The Scientific Community Must Distinguish Analysis from Advocacy, 416 NATURE 367, 367 (2002) (bemoaning the fact that "[s]cience is becoming yet another playing field for power politics, complete with the trappings of media spin and a win-at-all-costs attitude"). 
justify the action by invoking the statement will likely allow the administration to escape meaningful political accountability. ${ }^{196}$ The one thing that courts are not willing to police, and appropriately so, is the truth and completeness of political statements. It may be precisely to avoid the lack of judicial suitability to determine the legitimacy of political rationales that courts use the hard-look test.

\section{B. Scientific Veracity}

Professor Watts claims, as a second benefit, that allowing agencies to rely on politics will relieve them of pressure to justify decisions based on science, and thereby will encourage them to be more forthright about scientific issues. ${ }^{197}$ She notes that agencies have been criticized for distorting science. ${ }^{198}$ Although she claims not to rely on the truth of these criticisms, she nonetheless finds that allowing agencies to rely on political influence to justify decisions to courts would relieve pressure on them to mischaracterize science. ${ }^{199}$ Implicit in her argument therefore is a belief that agencies do massage science to make their rules seem more attractive to reviewing courts. ${ }^{200}$

To understand how Watts's focus on scientific truth is misplaced, it is imperative to understand the "science charade" in which agencies engage. ${ }^{201}$ Rarely do agencies simply assert a false scientific fact. ${ }^{202}$ Rather, their scientific inaccuracy involves characterizing decisions that seem scientific in nature but actually depend on value judgments as scientifically justified. ${ }^{203}$ For example, the Occupational Safety and Health

196. See Guido Pincione \& Fernando Téson, Rational Choice and Democratic DELIBERATION: A THEORY OF DisCOURSE FAILURE 16 (2006) ("[t]he public frequently errs about whether the policies they prefer will bring about the outcomes they prefer.").

197. Watts, supra note 7, at 40-41.

198. Id.

199. Id.

200. Id. at 40 ("Under the current technocratic model's focus on facts and evidence, agencies have an incentive to dress up their decisions in technocratic terms and to hide political influences. Agencies, accordingly, may well be tempted to align facts and science with political choices rather than giving science its own rightful place that is separate from political or value-laden considerations.").

201. Professor Wendy Wagner coined the term "science charade" in her seminal article. Wendy E. Wagner, The Science Charade in Toxic Risk Regulation, 95 COLUM. L. REV. 1613, 1617 (1995).

202. See id. at 1620-22.

203. Id. These value judgments in the scientific process have been described as trans-science. See Alvin M. Weinberg, Science and Trans-Science, 10 MinERVA 209 (1972). Trans-science exists when one of two conditions is met: "1) scientists would ultimately agree that selection of the most appropriate hypothesis among a range of possible alternatives is based not on data or scientific experimentation, but instead on nonscientific factors; or 2) the magnitude of the difference between warring 'camps' of scientific judgment is substantial." Wagner, supra note 201, at $1620 \mathrm{n} .22$; see also 
Administration (OSHA) might set a "safe" exposure limit for a carcinogen using a particular model of how such substances cause cancer. But, that model may be one of several that scientists are still debating, ${ }^{204}$ and its choice need not reflect any scientific superiority. Rather, the choice might reflect how aggressively the agency wants to protect against the possibility that workers will develop cancer. Alternatively, the choice might reflect the social costs of implementing the standard to which the model leads. ${ }^{205}$ These criteria are not matters of science. They are matters of policy that reflect an agency's underlying evaluation of various trade-offs of regulation. Science, however, is not irrelevant to the agency's policies. Science is fundamental in identifying the choices that a decision entails, whether those are choices about how science is carried out, or the ultimate choice between the benefits and costs of the decision.

Armed with this understanding of agency use and misuse of science, I see two problems with Watts's claim. First, and most significantly, she treats agency scientific inquiry as an end in itself that is separable from policy. ${ }^{206}$ But agency science is really an intermediate step in the process of enabling the agency to evaluate its regulatory decisions. The goal of judicial review with respect to an agency's scientific determinations is to encourage the agency to evaluate relevant science carefully and accurately identify the value choices effectuated by its actions. In addition, judicial review forces the agency to reveal the judgments on which its actions depend. Watts's proposal essentially extends an agency's ability to hide its value judgments to another dimension; the proposal might decrease agency lying, but it would do so by obviating the need for agencies to focus on science at all. Thus, it would sacrifice the ultimate goal of transparency of agency decision-making. Second, even focusing solely on scientific veracity, in many instances her proposal is likely to exacerbate agencies' mischaracterization of science.

Meazell, supra note 39, at 743 (“Although traditional science is infused with policy decisions, agency science is even more so because it is conducted for different purposes. That is, agency science is marshaled to fulfill legal standards in statutes consistent with executive-branch policy.”).

204. For a discussion of these possible dose-response functions, see generally Carol L. Silva \& Hank C. Jenkins-Smith, The Precautionary Principle in Context: U.S. and E.U. Scientists' Prescriptions for Policy in the Face of Uncertainty, 88 SoC. SCI. Q. 640 (2007).

205. See Meazell, supra note 39, at 744-45 (noting that "OSHA must consider the requirements of its statutory mandate, the current administration's policy goals, the costs and benefits of regulation, and the like, in addition to the limited scientific information, in coming up with a single number that regulates workplace exposure").

206. This is evident from Watts's focus on concerns that "[a]gencies ... [might] be tempted to align facts and science with political choices rather than giving science its own rightful place ...." Watts, supra note 7, at 40 . 
One motivation for an agency to inaccurately characterize a decision as science-driven is to allow the agency to create the impression of objectivity when explaining why its rulemaking decisions are consistent with scientific criteria imposed by its enabling act. ${ }^{207}$ In essence, an agency might mischaracterize whether an outcome in a rulemaking issue is scientifically determined because it fears that if it told the truth, it would be statutorily precluded from regulating as it wishes. In most cases, however, statutory standards do not limit relevant considerations to science alone, and agencies could explain why they made a particular scientific call in light of other factors they are permitted to consider. ${ }^{208}$ Where, however, the statute really does require a definitive scientific determination, tolerating dishonesty allows the agency to transcend the rule of law.

Watts recognizes this and is careful to limit her proposal to those situations where the enabling act allows the agency to rely on politics, ${ }^{209}$ which for her is when the enabling act does not preclude use of political factors. ${ }^{210}$ Hence, her proposal would not technically apply when an agency must demonstrate the existence of scientific prerequisites. But, because her proposal is limited in this way, it cannot reduce the propensity of the agency to misuse science when statutory prerequisites exclude policy considerations.

207. Statutes that provide at least some scientific criteria that an agency must consider when regulating are legion. See, e.g., Clean Air Act, 42 U.S.C. § 7409(b)(1) (2012) (National ambient air quality standards must "attain[] and maintain[] . . a an adequate margin of safety ... requisite to protect the public health."); Endangered Species Act, 16 U.S.C. § 1533(b)(1)(A) (2012) (listing of endangered species is to be based "solely on ... the best scientific and commercial data available"); Occupational Safety and Health Act 29 U.S.C. § 655(b)(5) (2012) (Toxics in the workplace are to be set at a level "which most adequately assures, to the extent feasible, on the basis of the best available evidence, that no employee will suffer material impairment of health ....").

208. See Wagner, supra note 201 , at $1667-68$ \& n.201 (claiming that only the Clean Air Act and the Delaney Clause of the Food and Drug Act preclude regulators from considering costs and feasibility). Arguably, the listing of endangered species also cannot be based on economics or feasibility of protection, although the statute provides for the "God Squad" to make exceptions allowing extinction of a species when the negative ramifications of maintaining the species are extreme. See 16 U.S.C. § 1536 (e)(1)-(2), (h) (authorizing the Endangered Species Committee, comprised of seven specified federal officials, to grant agencies exemptions from the Endangered Species Act in limited circumstances).

209. Watts, supra note 7, at 46 (noting that it would be inappropriate for an agency to rely on politics when Congress has explicitly limited determinations to those based on science); see also id. at 52 (expressing that her proposal not apply if "a statute explicitly or implicitly forecloses political considerations from an agency's calculus altogether (as the ESA's 'best science' standard appears to do with respect to the listing of endangered species)").

210. Watts, supra note 7, at 52; see also Pierce, What Factors Can an Agency Consider, supra note 29, at 71 (stating "[a]n [a]gency [c]annot [c]onsider a [f]actor Congress [p]rohibited it [f]rom [c]onsidering"). 
That still leaves the question: what role does science play when Watts's proposal does apply - that is, when agencies do not face statutes with scientific limitations? This is an important set of circumstances, because agencies may believe that decisions couched as science enjoy superdeference $^{211}$ and that characterizing decisions as scientific will greatly increase their probability of surviving arbitrary and capricious review. Agencies, however, do not engage in scientific inquiry for the sake of producing science. They are not centers of pure research. For agencies, science is instrumental to their regulatory decisions. ${ }^{212}$ That agencies mischaracterize the state of science to avoid revealing policy reinforces that agency truth-telling is not the ultimate end of agency decisionmaking. Rather, truth-telling is a means to ensure agency accountability for rulemaking by facilitating communication to the public of the rule's likely impact. Although Watts's proposal might reduce the incentive for agencies to lie about science, it will do so without forcing the agency to reveal the justification for its regulation.

An illuminating analogy would be a law that requires sellers of residential property to reveal whether they have knowledge of material defects - such as termite infestations or hidden damage to the property they are selling. ${ }^{213}$ Not infrequently, sellers lie about such knowledge. ${ }^{214}$ Watts's proposal would be analogous to a legal doctrine that rescinded a seller's obligation to disclose such information. That would certainly decrease the seller's need to lie and almost certainly would decrease the extent of such lying. But, it would not serve the ultimate goal of informing

211. Super deference is best characterized by the Supreme Court's statement in Baltimore Gas \& Elec. v. Natural Res. Def. Council that when a court reviews an agency's scientific determinations "within its area of special expertise, at the frontiers of science .... a reviewing court must generally be at its most deferential." 462 U.S. 87, 103 (1983). This gives agencies an incentive "to cloak their policy choices in the seemingly unassailable mantle of science" in order to survive judicial review. Meazell, supra note 39, at 736.

212. See Sheila Jasanoff, the Fifth Branch: Science AdVisors as Policymakers 77 (1990) (stating that the purpose of agency science is to "produce 'techniques, processes and artifacts' that further the task of policy development"); Meazell, supra note 39, at 743 (asserting that "science in agencies is far removed from the stereotypical academic research setting . . . . because it is conducted for different purposes").

213. Many states have codified the duty to disclose. See, e.g., CaL. CIV. CodE $\S 1102.6$ (West 2011) (requiring property sellers to fill out a disclosure checklist); WIS. STAT. ANN. § 709.03 (West 2011). Additionally, many state courts have imposed such an obligation as a matter of contract law. See, e.g., Johnson v. Davis, 480 So. 2d 625, 629 (Fla. 1985) ("where the seller of a home knows of facts materially affecting the value of the property which are not readily observable and are not known to the buyer, the seller is under a duty to disclose them to the buyer").

214. See, e.g., Harding v. Willie, 458 N.W.2d 612, 614 (Iowa Ct. App. 1990) (buyer rescinded a contract when he found that the roof leaked after the seller said there was "absolutely no problem" with the roof). 
buyers about the seller's knowledge. In contrast, the hard-look test is analogous to a legal doctrine that requires a court to inquire whether the seller lied and imposes liability if the court determines that he did. Thus, if courts inadvertently encouraged agencies to mischaracterize decisions as objectively scientific by affording scientific determinations superdeference, the ideal judicial response would be to abandon such deference for a doctrine that ferrets out the value judgments behind the agency decision, rather than allow the agency to invoke politics to avoid discussing the value judgments that attach to the scientific predicates for its action.

Even if we accept that reducing agency misrepresentation of science is a laudable goal in its own right, there are reasons why Watts's proposal might actually promote such disingenuity. A fairly common explanation for an agency being less than truthful about scientific and technical matters is to avoid adverse political ramifications. ${ }^{215}$ That is, an agency may mischaracterize science even when telling the truth would not preclude it from regulating under its enabling act. Why might an agency do so when it could pass judicial muster by being forthright? The question is especially puzzling given that, under current judicial standards, the agency can be reversed for lying even if its rule would have been upheld had it been truthful. ${ }^{216}$ The answer reflects that an agency will want to hide the truth in some instances because the truth would undermine support for a "political" decision that is based on an unpopular ideological position or a desire to deliver rents to political supporters. Allowing an agency to justify an action merely by invoking public presidential support may create an incentive for the president to mischaracterize the action as scientifically based to make it appear more objectively justified than it is. ${ }^{217}$ In short, by

215. See JASANOFF, supra note 212, at 242 (noting that agency delegation of fundamentally political problems to technical advisory committees "remains one of the most politically acceptable options" open to regulators); Wagner, supra note 201, at 1652-53 (suggesting that concealing political compromises "under [a] veneer of scientific truth" is often seen as the only means of pacifying a public that demands mutually exclusive regulatory goals).

216. See, e.g., Sierra Club v. U.S. Army Corps of Eng'rs, 701 F.2d 1011, 1030-32, 1034 (2d Cir. 1983) (finding that the Corps violated NEPA and acted arbitrarily and capriciously by accepting conclusions that the Hudson River inter-pier area in Manhattan was a biological wasteland).

217. As two well-regarded scholars of public policy have noted, "[s]cience has considerable rhetorical appeal when it comes to defending regulatory decisions, as it is often described and perceived as being 'objective." Cary Coglianese \& Gary E. Marchant, Shifting Sands: The Limits of Science in Setting Risk Standards, 152 U. PA. L. REV. 1255, 1264 (2004); cf. Dan M. Kahan, The Supreme Court 2010 Term-Foreword: Neutral Principles, Motivated Cognition, and Some Problems for Constitutional Law, 125 HARV. L. REV. 1, 35 (2011) (opining that "[t]he contribution empirical arguments are thought to make to muting contested values is part of their appeal in political discourse generally"). 
relaxing hard-look review when an agency relies on political influence, Watts provides more room for the administration to mischaracterize science outside of the agency justification for its action.

The recent case of Massachusetts v. EPA ${ }^{218}$ may provide an interesting example of this phenomenon. In that case, the agency attempted to characterize its decision not to regulate as based on the need for a comprehensive regulatory approach and international politics rather than science, which is the flip side of the usual case of the science charade. ${ }^{219}$ The EPA may have wanted to downplay science because the Bush Administration had publicly relied on uncertainty about the anthropogenic connection to climate change in its attempts to win popular support for its position of not taking action to reduce greenhouse gas emissions. ${ }^{220}$ Given that public stance, it would have been difficult for the administration to admit that global warming was real and that it might threaten a magnitude of environmental harm that exceeds most other such harms posed by human activity. ${ }^{221}$ It was easier and less embarrassing to convince the public that the science of global warming is uncertain than to convince them that the government cannot cure the problem that exists. ${ }^{222}$

218. 549 U.S. 497 (2007)

219. Id. at 497, 513. After exhausting statutory reasons for not regulating greenhouse gases, the EPA first "gave controlling importance to the NRC Report's statement that a causal link between [human activities and global warming] 'cannot be unequivocally established."' $I d$. at 513 . The EPA then characterized "regulation of motor-vehicle emissions as a 'piecemeal approach' to climate change and stated that such regulation would conflict with the President's 'comprehensive approach' to the problem." Id. (citations omitted). Finally, the EPA reasoned that "unilateral EPA regulation of motorvehicle greenhouse gas emissions might also hamper the President's ability to persuade key developing countries to reduce greenhouse gas emissions." Id. at 513-14.

220. On several occasions very early in President Bush's first term in office, he claimed to take a leadership role on global warming, but relied on scientific uncertainty about anthropogenic climate change to justify not acting to address the problem. See, e.g., Letter from President George W. Bush to Senators Hagel, Helms, Craig and Roberts (Mar. 13, 2001), available at http://georgewbushwhitehouse.archives.gov/news/releases/2001/03/20010314.html (last checked Aug. 25, 2011) (expressing unwillingness to regulate $\mathrm{CO}_{2}$ emissions because of "the incomplete state of scientific knowledge of the causes of, and solutions to, global climate change."); see also Press Briefing, President George W. Bush at the White House, June 11, 2001 ("We do not know how much our climate could, or will change in the future. We do not know how fast change will occur, or even how some of our actions could impact it.... My administration is committed to a leadership role on the issue of climate change").

221. See National Research Council of the National ACademies Committee on AmericA's Climate Choices, AmericA's Climate Choices 20-23 (2011) (reporting on past and possible future effects of climate change).

222. The manipulability of science is illustrated by the fact that a significant percentage of the American public is even skeptical of such a well-accepted scientific truth as evolution. See generally Jason R. Wiles, Overwhelming Scientific Confidence in Evolution and Its Centrality in Scientific Education-And the Public Discontent, 9 SCI. EDUC. REV. 18 (2010) (reporting the "overwhelming acceptance of evolution among scientists" but that "a strikingly large proportion of North Americans reject evolution"). Ernst Mayr, Professor of Biology at Harvard, has characterized the evidence for the 
Thus, Massachusetts v. EPA may represent a case in which the agency mischaracterized science not to pass judicial review, but to bolster public support for the administration's policy. Watts explicitly cites this case as an indication that the Court requires agencies to provide technocratic reasons for its decisions. ${ }^{223}$ She thus sees Massachusetts v. EPA as downplaying the legitimacy of political influence to something that may at most influence agencies after they give satisfactory scientific explanations for their actions. ${ }^{224}$ Although she admits that Massachusetts v. EPA may be sui generis, ${ }^{225}$ she sees it potentially as a strong indication that courts reject political influence as an explanation for agency decision-making. ${ }^{226}$ But one can just as easily read Massachusetts v. EPA as the backfiring of the Administration's attempt to misuse agency science to shore up political support. By the time Massachusetts v. EPA was presented to the Supreme Court, the scientific case that climate change was due to humantriggered emissions of greenhouse gases was well accepted. ${ }^{227}$ The Court's opinion was sufficiently in tension with prior law such that one might read it to signal antipathy by the majority towards the agency's mischaracterization of science for political purposes. ${ }^{228}$

occurrence of evolution as so overwhelming that biologists "consider it a fact-as well-established as the fact that the Earth rotates around the sun and that the Earth is round and not flat." ERNST MAYR, THIS IS BIOLOGY: THE SCIENCE OF THE LIVING WORLD 178 (1997). By comparison, between 1985 and 2005, the percentage of adults in the United States who believed that "Human Beings . . . developed from earlier animals" ranged from $40-45 \%$ while the number of such adults who believed that statement to be false ranged from 39-48\%. Jon D. Miller et al., Public Acceptance of Evolution, 313 SCIENCE 765, 765 (2006)

223. Watts, supra note 7, at 21-22.

224. Id.

225. Id. at 50-51 (noting that "Massachusetts was not a normal, run-of-the mill case").

226. Id. at 22. In Watts's words, "Massachusetts loudly reiterates the message that State Farm has been read to have established more than twenty years earlier: agencies must justify their decisions in expert-driven, not political, terms if they wish to convince courts that reasoned decisionmaking has occurred." Id. But even Watts acknowledges that the Massachusetts majority seemed to allow agencies to consider politics, after providing a satisfactory technocratic reason for its action. See Watts, supra note 7, at 49-50. This reading of the case is consistent with my view of hard-look review, which freely allows agencies to consider politics and to make value judgments based on political influence, so long as the agency provides sufficient reasoning to make those judgments transparent.

227. See Burning Bush, The EconOMIST, June 14, 2001, at 77. Even President Bush's own commissioned report by the National Academy of Sciences (NAS) concluded, "Greenhouse gases are accumulating in Earth's atmosphere as a result of human activities ... . Human-induced warming and associated sea level rises are expected to continue throughout the 21st Century." Id.

228. Several scholars read Massachusetts v. EPA as signaling a rejection of the understanding that an agency can rely on factors extraneous to its enabling act to justify a decision not to regulate a problem within the agency's authority. See, e.g., Jack M. Beermann, The Turn Toward Congress in Administrative Law, 89 B.U. L. REv. 727, 740 (2009) (reading Massachusetts v. EPA to support that "an agency . . . must consider Congress's factors rather than the agency's or the administration's preferred factors"); Pierce, What Factors Can an Agency Consider, supra note 29, at 79 (expressing "fear that the majority opinion in Massachusetts will be interpreted to reject the long line of D.C. 
Most significantly for this Article, assuming that Watts means to suggest that Massachusetts $v$. EPA would come out differently under her proposal, ${ }^{229}$ the case illustrates how that proposal would allow an agency to avoid paying the costs of mischaracterizing science for political purposes by circumventing the usual hard-look review. To be clear, I do not support the detailed reasoning of the majority in that case. I believe that the Court was incorrect to read the Clean Air Act to require the Administrator either to make the determination whether greenhouse gases threaten public health and the environment or explain in scientific terms why such a determination could not be made. Like other scholars, I too am worried that the case might presage a judicially created restriction on the factors an agency can cite in rejecting a petition to engage in rulemaking. ${ }^{230}$ But, to the extent that hard-look review applies to that decision, ${ }^{231}$ the Court was correct to have required that the EPA be honest about the connection of climate change and human conduct. I believe that the Court was also correct to demand that the EPA provide some indication of the likely trade-offs between regulating and not regulating that would justify the Administrator's decision not to inquire into the health and environmental effects of automobile emissions.

Perhaps the scenario that provides the strongest case for Watts's proposal would involve an agency mischaracterizing science out of fear that a reviewing court would not understand a true exposition. If the science is truly complex or controversial and the agency fears that a court will simply not comprehend the science sufficiently to understand the basis for a regulation, the agency might be tempted to obscure the discretionary judgments underlying its scientific determinations. In short, the agency might try to avoid mistaken judicial reversal of its science by simply characterizing its decision as being objectively mandated and hoping that it does not get caught. Watts's proposal would avoid having the agency engage in such a charade, and would prevent erroneous reversal by courts in such a situation.

Circuit opinions ... interpret[ing] congressional silence to permit an agency to consider a logically relevant decisional factor").

229. Although Watts does not explicitly opine that the case would come out differently under her test, she suggests as much by her acknowledgment that the case most naturally (but not necessarily) can be read to preclude agency reliance on non-statutory factors such as politics to justify its decision. Watts, supra note 7 , at $49-51$.

230. See supra notes 226 and 228 and accompanying text.

231. Lower courts usually do not apply hard-look review to agency decisions to refrain from rulemaking unless the decision is one made on the merits based on factors that the courts are capable of evaluating. See, e.g., Prof'1 Pilots Fed'n v. FAA, 118 F.3d 758, 764 (D.C. Cir. 1997). 
Even in this scenario, however, there are problems with Watts's proposal. First, without a court engaging in full-fledged hard-look review, there is no way to distinguish when an agency mischaracterizes scientific determinations to bypass the potential that courts will not understand the issue versus when it does so to avoid revealing illegitimate or politically unacceptable rationales. Thus, although Watts's proposal might make sense when an agency simply takes a "short cut" by mischaracterizing its seemingly scientific determinations, it would invite agencies to avoid such explanations even when the agency knows that the avoidance of revealing its value judgments is problematic.

Moreover, the costs of having a decision reversed because the reviewing court did not sufficiently understand the science are unlikely to be great. Although courts vet agency technical decisions to ensure that agencies carefully consider all relevant issues, courts generally do not second-guess agency technical decisions when those decisions address all the data and arguments that the reviewing court finds relevant. ${ }^{232}$ The problem judicial review of technical determinations poses for the agency is that the courts might not even know enough to understand what data and inquiries are truly relevant. ${ }^{233}$ Thus, when courts reverse determinations of science that can be supported, they generally do so on grounds that aspects of the problem were insufficiently addressed. In such a situation, however, with the benefit of a judicial opinion explaining what the court thought the agency got wrong, the agency can reissue its decision, in the vast majority of cases, explaining why it believes it was correct in the first place. ${ }^{234}$ In particular, the agency can home in on why the court misunderstood the science or otherwise got the issue wrong. ${ }^{235}$ One could expect that when a court remands a rule for which the agency has valid scientific support,

232. Such decisions would rely on the clear error of judgment prong alone to justify reversing an agency policy. Courts rarely so rule. See supra note 96 and accompanying text.

233. See Stephenson, "Hard Look" Judicial Review, supra note 28, at 754-55; Thomas O. McGarity, The Courts and the Ossification of Rulemaking: A Response to Professor Seidenfeld, 75 TEX. L. REv. 525, 547 (1997) (critiquing review of an agency rule on grounds that "[t]he judges . . lacked the breadth and depth of experience and expertise necessary to support [their] confident assertions about how the agency should go about its assigned business").

234. See generally William S. Jordan, III, Ossification Revisited: Does Arbitrary and Capricious Review Significantly Interfere with Agency Ability to Achieve Regulatory Goals Through Informal Rulemaking?, 94 Nw. U. L. REV. 393 (2000) (reviewing the ultimate fate of rules remanded as arbitrary and capricious).

235. See id. at 424-25 (detailing how, in a majority of remanded rules studied, the agency was able to explain itself and persuade the reviewing court to accept essentially the same rule that it had earlier reversed); Emily Hammond Meazell, Deference and Dialogue in Administrative Law, 111 Colum. L. ReV. 1722, 1735 (2011) (describing how judicial remands can signal to an agency the court's "understanding of the scientific, technical, and policy considerations at issue"). 
ultimately the agency will prevail and will get to adopt its rule, albeit a bit delayed.

Finally, whether or not an agency decision is ultimately defensible on judicial review, Watts's proposal deprives the agency, as well as the public, of the information about the trade-offs inherent in agency regulation. Even if the agency believes that its mischaracterization of science is merely a short cut to get to the outcome that the polity prefers, the agency itself might be mistaken. One of the salutary attributes of hardlook review is that it may be the only time the agency's detailed technical judgments are questioned in the entire rulemaking process. ${ }^{236}$ The prospect of such review encourages the agency staff to take greater care in evaluating its own technical assessments, and may allow it to find errors or correct parochial outlooks of staff members who may harbor biases that stem from their professional background. ${ }^{237}$ Thus, Watts's proposal would increase the likelihood that the agency will avail itself of the political influence justification rather than ensure that the regulation is one that it believes is truly justified.

\section{Ameliorating Ossification of Regulation}

Another of Watts's normative claims is that her proposal would help alleviate the ossification of rulemaking that scholars have claimed plagues the regulatory process. ${ }^{238}$ But in the context of any particular rulemaking, it is not self-evident whether the regulatory process wastes agency resources and imposes unnecessary delay, or is instead worthwhile to encourage the agency to evaluate its policy as carefully as is warranted. Moreover, agency adoption of regulations provides benefits and detriments to those in the agency that do not necessarily correlate with those provided to society. ${ }^{239}$ Thus, in those instances where an agency has an incentive to adopt regulations that do not provide net benefits to society, ossification of the regulatory process would be desirable because it would discourage such regulations.

236. William F. Pederson, Jr., Formal Records and Informal Rulemaking, 85 YALE L.J. 38, 59-60 (1975).

237. Id. at 60. "The effect of [hard-look review] opinions within the agency reaches beyond those who were concerned with the specific regulations reviewed. They serve as a precedent for future rulewriters and give those who care about well-documented and well-reasoned decisionmaking a lever with which to move those who do not." Id.; see also Seidenfeld, Cognitive Loafing, supra note 63, at 509-12.

238. Watts, supra note 7, at 41-42.

239. Seidenfeld, Why Agencies Act, supra note 68, at 252. 
To illustrate, consider a world in which much of what agencies do is create rents and deliver them to well-connected interest groups. In such a world, much agency action would not further the public interest; hence, delay and discouragement of an action would be beneficial. In some instances, however, agency regulation does further the public interest. In these instances, it would be better to encourage and speedup regulation. Therefore, what is needed is a mechanism that differentially burdens agency action - heavily burdening rent creation and only lightly burdening regulation in the public interest.

It is just such a notion of differential burden that explains, in part, the constitutional requirements of bicameralism and presentment of legislation. ${ }^{240}$ One can make the legislative process much easier and quicker by empowering either house to pass a law without the president's signature. But a bill that significantly harms the public overall is unlikely to pass through the full Article I process because the beneficiaries of such a bill have to line many more campaign committee coffers and compete with other interest groups that may oppose them on a national basis to secure the support of both houses and the president. ${ }^{241}$ Therefore, according to this view of bicameralism and presentment, the resulting decrease in the ossification of the legislative process would not be good because it would greatly enable more bad legislation while only mildly facilitating good legislation.

At the administrative level, hard-look review plays somewhat the same role that bicameralism and presentment are meant to play at the legislative level. The burden it creates is greater for agency regulation that cannot be justified after objective presentation of the implications of the regulation, compared with alternatives that the agency could pursue. For a regulation that cannot be justified, the agency might try to obscure the effects of the regulation to avoid paying the political cost if the regulation is revealed as serving special interests. One way the agency might obscure those effects is to justify the rule based on platitudes announced by the president in

240. Historically, bicameralism and presentment were seen as a means of simply discouraging all federal lawmaking, as well as a means of differentially burdening bad lawmaking. John F. Manning, Textualism and the Equity of the Statute, 101 Colum. L. Rev. 1, 72-73 (2001); see also Michael B. Rappaport, Amending the Constitution to Establish Fiscal Supermajority Rules, 13 J.L. \& PoL. 705, 712 (1997) (stating that bicameralism establishes an effective supermajority which discourages both minority control of the legislative process and interference with property rights); William T. Mayton, The Possibilities of Collective Choice: Arrow's Theorem, Article I, and the Delegation of Legislative Power to Administrative Agencies, 1986 DuKE L.J. 948, 956-57 (1986) (explaining how bicameralism promotes rational lawmaking).

241. See Mayton, supra note 207, at 954, 956-57. 
support of the rule. Therefore, although Watts's proposal undoubtedly will increase the ease with which agencies can regulate, it is very likely that the increase will facilitate adoption of rules that benefit connected interest groups at the expense of the national welfare more than rules that serve a broader public interest.

\section{THE IMPROPRIETY OF JUDICIAL EVALUATION OF POLITICAL INFLUENCE}

My final concern with factoring political influence into judicial review of whether a regulation is arbitrary and capricious stems from the inherent impropriety of having courts determine when political influence is legitimate. It is imperative to understand that consideration of political influence under arbitrary and capricious review is not grounded in any assessment of whether adoption of a regulation has violated the Constitution or any statutory prescription. Watts would have the courts assess whether political influence on which an agency might rely is sufficiently grounded in "public values." 242 Given that there are no broadly accepted criteria for distinguishing legitimate from illegitimate political influences, however, Watts's proposal either would eviscerate meaningful arbitrary and capricious review or inappropriately rely on judges to weigh the import of such influence. ${ }^{243}$

242. See Watts, supra note 7, at 53-54. Watts also would require that the political desire be communicated to the agency in a sufficiently transparent manner. Id. at 8 . Although this requirement raises a host of questions about possible constitutionally based prerogatives of the White House to communicate with government officials in private, those questions involve different sorts of critiques from those I address in this article, and hence, I leave them to another day. Cf. Watts, supra note 7 (clarifying that her article does not address Nina Mendelson's call for greater transparency of presidential influence on agency rulemaking).

243. Watts recognizes that there is a "normative question of whether judges ought to be searching for public values to support governmental decisions." Watts, supra note 7, at 53. But, she leaves that question aside because, she claims, judges are comfortable searching out public values in determining the constitutionality of statutes. Id. Her support for such judicial comfort, however, is citation to Cass R. Sunstein, Naked Preferences and the Constitution, 84 ColuM. L. REv. 1689, 1692 (1984). But the determinations that Sunstein discusses occur as part of the Court evaluating whether the government has relied on constitutionally prohibited factors. See, e.g., Cass R. Sunstein, Naked Preferences and the Constitution, 84 Colum. L. REV. 1689, 1710-17 (1984) (discussing how the prohibition on government reliance on naked politics works under the various standards of the equal protection clause). Thus, the search for public values reflected in existing cases may be better viewed as an inquiry into whether specific prohibited constitutional criteria were responsible for the political action. And the varied standards of review may be seen to reflect the a priori likelihood that the political actors did rely on impermissible factors. This involves a very different kind of evaluation of whether government action serves public values than Watts's proposal would require. See supra note 216 and accompanying text. 
Watts would ground legitimacy in a requirement that political influence be based on "public values" rather than "pure partisan politics." 244 Although she never defines these terms, her discussion and examples imply that it would be illegitimate for an agency to rely on political influence by simply asserting that it adopted a regulation because that is what the president demanded or because he desired the regulation to pay back his political supporters. ${ }^{245}$ Defining public interest based influence, however, as merely something distinct from what those with political power want, provides little purchase in distinguishing a regulation that can be justified as reflecting legitimate politics from that which cannot. Any government action can be framed as serving some purpose other than merely satisfying the preferences of those in political power. Today, redistributing wealth is generally accepted as a legitimate role for government so long as the redistribution can be justified by some notion of morality or dessert. ${ }^{246}$ For example, one can justify a tax increase on the wealthy together with a program of benefits for the poor as a means of improving the lot of the unfortunate in society who are least well-off. One can also justify the exact opposite - a tax decrease on the wealthy and a cutback on benefits to the poor - on the ground that the wealthy pay more than their fair share for what government provides. Given the legitimacy of wealth redistribution, there is virtually nothing that cannot be justified, at least facially, on grounds other than pure political power. ${ }^{247}$

In fact, given the general discontent of the populous with naked assertions of political power, politicians have great incentive to hide such

244. Watts, supra note 7 , at 54 .

245. Id. at 53-57. There seems to be broad scholarly consensus that such reasons do not legitimately justify agency action. See, e.g., Bressman, Beyond Accountability, supra note 17, at 50405; Mashaw, supra note 19, at 95; Mendelson, "Political" Oversight, supra note 7, at 1175-76.

246. See Douglas W. Kmiec, Introduction to the 2006 Templeton Lecture: Hitting Home-The Supreme Court Earns Public Notice Opining on Public Use, 9 U. PA. J. Const. L. 501, 530 (2006) ("I don't think any legitimate argument can be made that ... wealth redistribution is impermissible."); Frank I. Michelman, Property, Utility, and Fairness: Comments on the Ethical Foundations of "Just Compensation" Law, 80 HARV. L. REV. 1165, 1181 (1967) ("Few people any longer doubt that governments are properly engaged in controlling the distribution of wealth and income among members of society. . . ."); Cass R. Sunstein, On Property and Constitutionalism, 14 CARDOZO L. REV. 907, 917 (1993) (stating that wealth redistribution "programs are a necessary part of any system of property rights"); cf. Louis Kaplow \& Steven Shavell, Why the Legal System Is Less Efficient than the Income Tax in Redistributing Income, 23 J. LEGAL STUD. 667 (1994) (arguing that taxation rather than legal rules it the best way to redistribute income). But see RICHARD A. EPSTEIN, TAKINGS 29899, 314-24 (1985) (contending that redistribution of wealth is not a legitimate public purpose of government).

247. See PinCIONE \& TÉSON, supra note 196, at 18, 217 (noting the relationship of government power to redistribute wealth and "discourse failure"). 
assertions behind seemingly legitimate reasons. ${ }^{248}$ Hence, political influence will virtually always be shrouded in some invocation of other values. If all that "based on public values" means is that some rationale other than a pure exercise of political power can be asserted for a regulation, then Watts's proposal would essentially eviscerate the arbitrary and capricious standard whenever the president expressed a desire for a regulation. The unfortunate result would be that agencies would be freed from having to collect and analyze information that would shed light on the trade-offs and value judgments underlying the regulation - the precise information that is needed to make political accountability meaningful.

A careful reading of Watts's proposal suggests that she would have courts make a finer distinction than merely acquiescing in political statements framed in terms other than raw political power. Her modification of hard-look review identifies politics as one factor courts should consider along with technocratic information. ${ }^{249}$ She concedes that under her proposal courts would have to weigh political influence and balance it against other factors that they consider under hard-look review. ${ }^{250}$ But if that were the case, then courts would have to determine not only whether political influence of regulation was an assertion of pure political power, but also whether it was sufficiently publicly interested to overcome any shortcoming in the agency analysis of the rule under the current hard-look standard. ${ }^{251}$ Having courts make that determination is extremely problematic. $^{252}$

Most obviously, courts can claim neither political stature nor any special skill at divining whether the outcome of the political process, be it statute or regulation, comports with the values and preferences of the polity. Courts are insulated from political accountability and have no inherent claim to assessing the weight of appeals to politics. ${ }^{253}$ Nor are

248. Id. at 18, 217 (stating that "[d]iscourse failure ... results from [among other things] the incentives of politicians and lobbyists to spread inaccurate views" and that "vote seeking politicians" have an incentive to engage in "posturing"); Watts, supra note 7, at 82-84.

249. Watts, supra note 7 , at 84 .

250. Id. at $82-83$.

251. Cf. id. at 53 (explicitly declining to evaluate the propriety of judges "searching for public values to support government decisions.").

252. See Mendelson, "Political" Oversight, supra note 7, at 1131 (expressing concern that proposals having courts consider political influence on agency decision-making "place an inappropriate burden on the judiciary to distinguish good and bad political reasons").

253. See Douglas W. Kmiec, Judicial Deference to Executive Agencies and the Decline of the Nondelegation Doctrine, 2 ADMIN. L.J. 269, 269-70 (1988) (arguing that "it is analytically inconsistent and contrary to the assignment of political responsibility within our constitutional structure for the judiciary to tolerate liberal delegations of authority to executive agencies and, then, selectively undermine or displace that authority when it is exercised"); John F. Manning, 
courts trained in evaluating the breadth and depth of popular support for particular value judgments on which appeals to politics ultimately rest. Hence, in pragmatic instrumental terms, the judiciary seems a poor choice for evaluating the weight of political considerations. ${ }^{254}$

In addition, even if one believes that courts are the appropriate institution to weigh the extent to which an explanation for a rule reflects the public interest rather than raw politics, there is a pragmatic problem with having courts determine the legitimacy of political motivation. Virtually every agency action could be motivated by multiple considerations. ${ }^{255}$ Hence, under Watts's proposal, courts would have to decide the extent to which an action can be attributable to a particular motive and then evaluate the legitimacy of the various motives to determine whether political influence provides a boost or a barrier to passing judicial review.

Perhaps more significantly, at a theoretical level, I believe that Watts's proposal actually usurps a fundamental role of politics in the regulatory process. I understand democratic politics as the mechanism that allows government to act in the face of differences in values that cannot be resolved by objective rationality. It is politics that determines whether the process by which an agency translates those values into a regulation is valid. That is not to deny that there are legal constraints on agency rulemaking. But, as long as the agency acts in accordance with the Constitution and federal statutes, reveals the trade-offs inherent in is judgment, and does not simply assert that the rule is valid because it is simply preferred by the controlling political powers, it is up to the political process - ultimately backed up by the election of legislators and the president - to evaluate whether the value judgments underlying the regulation were warranted. ${ }^{256}$

Constitutional Structure and Judicial Deference to Agency Interpretations of Agency Rules, 96 Colum. L. REv. 612, 626 (1996) ("[F]ederal judges - who have no constituency - have a duty to respect legitimate policy choices of those who do."); Richard J. Pierce, Jr., Reconciling Chevron and Stare Decisis, 85 GEO. L.J. 2225, 2237 (1997) (opining that allowing judges to evaluate political controversies would result in outcomes that mirror each judge's policy preferences).

254. In fact, Article III's limitation of the judicial power to cases and controversies has been seen in part as a means of preventing the courts from interfering with policy decisions of the executive branch. See Seidenfeld, Chevron 's Foundation, supra note 31, at 289.

255. See Seidenfeld, Why Agencies Act, supra note 68, at 252-53 (noting that numerous factors, including personal incentives of agency staff members, agency heads, and institutional influences, can motivate an agency to act). Particular thanks to Ron Levin for this insight.

256. As one who believes in deliberative democracy, I would encourage regulators to consider the interests of all those affected and to try to find universal consensus on how to resolve the differences in value judgments. But I am not particularly sanguine about the prospects that all stakeholders can reach a consensus in any regulatory dispute. See Seidenfeld, Civic Republican, supra note 30, at 1538-39. 
For example, suppose that the FCC rule at issue in Fox Television, prohibiting the broadcast of fleeting expletives, was adopted at the request of the president but ultimately after the FCC fully analyzed the likely impact of the rule. Should a court hold that rule to be arbitrary and capricious if the president had explained his request as motivated by a desire to have the law reflect a greater value on decency in broadcast programming than the value prior administrations implicitly placed on it? I would think not. ${ }^{257}$

Current hard-look review would not invalidate the rule because of such an explanation. ${ }^{258}$ As long as the agency fully evaluated the circumstances surrounding the regulation and provided its best prediction of the regulation's effects compared to alternatives, hard-look review would be agnostic about the political influences that may have motivated the regulation. ${ }^{259}$ Essentially, hard-look review forces the agency to provide information that can allow better monitoring by interest groups and more informed judgment by voters about whether they agree with the values that underlie the decision. Ultimately, if many voters determine that they do not agree, then the administration at least faces the threat that it will pay some price at the polls. Although Watts clearly indicates that she thinks that such an invocation of values by the president is legitimate, her proposal nonetheless suggests that the reviewing court would have to evaluate the value of the particular public-regarding explanation and would treat the regulation differently depending on its answer to that question. ${ }^{260}$ To me, that does not seem to be judicial empowerment of political influence, but rather, judicial usurpation of it.

I do not mean to suggest that there is no distinction between publicregarding justifications for regulations and raw political ones. In fact I, along with others, have expressed a belief that the regulatory process should encourage officials to deliberate about the public good and to consider whether the regulation reflects a broadly shared consensus of the interests of the nation as whole. ${ }^{261}$ Therefore, the political process ideally

\footnotetext{
The best administrative law might be able to do is establish procedures and constraints that encourage input and empathetic deliberation, and then allow the system to operate with the expectation that the system will reach outcomes that are more sensitive to differences in values than they would be if the system were not set up to foster such deliberation.

257. As in Fox Television, I assume that whether this regulation violates the First Amendment is not under consideration. See 556 U.S. 502, 529 (2009).

258. See supra notes 80-85 and accompanying text.

259. See supra notes 63-66 and accompanying text.

260. Watts, supra note 7, at 82-84.

261. See Evan J. Criddle, When Delegation Begets Domination: Due Process of Administrative Lawmaking, 46 GA. L. REV. 117 (2011); Seidenfeld, Civic Republican, supra note 30, at 1571-73;
} 
should involve deliberation about the meaning of the public interest and rational evaluation about whether the regulation will further that interest. Ultimately, the agency should provide some explanation of why it believes its decision is good and not simply assert that it is the outcome the president desires. But to propose this as an ideal is very different from discrediting regulations that some judge finds was not sufficiently publicregarding. Having created a system that permits deliberation and evaluation of values, it seems inherently anti-democratic to force the polity to adopt some judge's notion of what constitutes a legitimate political reason in order to justify the regulation. If the polity ultimately prefers power politics to deliberation about the public interest, I do not see any legal basis for courts to override that preference.

Because Watts structures her incorporation of politics into hard-look review as a ratchet that helps and never hinders administrative agencies survive judicial review, my critique of judicial usurpation of political influence is less damning than if Watts had allowed such incorporation to lead courts to reverse agency regulation. One might argue that the critique is entirely misplaced because ultimately Watts's proposal makes it more likely that political judgments of agencies will prevail. But, as long as judicial evaluation of politics can make a difference in the outcome of review, Watts's proposal inappropriately involves courts in essentially non-legal determinations. ${ }^{262}$ For example, consider a regulation prompted by a public statement by the president explaining why he believes the regulation is good for the nation. Suppose also that the agency's record and explanation would not pass hard-look review because the agency left some question about the impact of the regulation insufficiently explored. Under Watts's criteria for legitimate political values, a judge that considers the policy to further the public interest rather than simply reflect special interest influence will vote to uphold the regulation, but one that finds the regulation merely delivers benefits to a politically connected interest group will vote to reverse it. ${ }^{263}$ Essentially, whether the regulation is held arbitrary and capricious will depend on the judge's evaluation of whether she thinks the policy is justified in terms of her personal view of

Cass R. Sunstein, Interest Groups in American Public Law, 38 STAN. L. REV. 29, 63 (1985) (positing that hard-look review attempts to ensure that an agency deliberates "in order to identify and implement the public values that should control the controversy"); Staszewski, Deliberative Democracy, supra note 12 , at $857-64$.

262. The distinction between law and politics in American government has been judicially recognized at least since Marbury v. Madison. 5 U.S. 137, 170 (1803).

263. See Watts, supra note 7, at 53-54. 
the public interest. This violates the very notion that judges determine and apply law.

Another possible response to my criticism of having courts evaluate political influence is that the reasoned decision-making standard is already sufficiently amorphous that it allows judges to rely on their personal policy preferences in evaluating whether a regulation is arbitrary and capricious. ${ }^{264}$ Critics of hard-look review are certainly correct that judges' disposition toward a rule-more particularly judges' predilections about whether an agency thought carefully enough about a rule that it issuedwill be influenced by their view of whether the rule is good policy. ${ }^{265}$ It is one thing, however, to employ a standard that allows judges to act on their policy preferences without inviting them to do so. It is quite another to create a standard that requires judges to evaluate the political worth of a regulation. ${ }^{266}$ In the former instance, most judges will be constrained from deciding based on their views of policy by a counterbalancing desire to be seen as good judicial crafts-persons and the related potential of harm to their reputations among their brethren and other members of the legal community. ${ }^{267}$ Under the latter standard, a judge can maintain a reputation for applying the law in an unbiased manner while imposing her policy

264. Cf. William N. Eskridge \& John Ferejohn, Structuring Lawmaking to Reduce Cognitive Bias: A Critical View, 87 Connell L. Rev. 616, 629 (2002) (questioning the impact of judicial accountability on agency decision-making because of doubts whether "judges engaging in hard-look review will or even can keep their views about the substance of regulations entirely separate from their views about the process").

265. See Frank B. Cross \& Emerson H. Tiller, Judicial Partisanship and Obedience to Legal Doctrine: Whistleblowing on the Federal Courts of Appeals, 107 YALE L.J. 2155, 2169 (1998) (finding that, in review of administrative agencies, D.C. Circuit panels with a majority of Republican appointed judges reached conservative outcomes in fifty-four percent of cases, whereas panels with a majority of Democratic appointed judges reached liberal decisions in sixty-eight percent of cases); Miles \& Sunstein, supra note 89, at 814 (concluding that hard-look review is "hardened, or softened, by the political predilections of federal judges"); Richard L. Revesz, Environmental Regulation, Ideology, and the D.C. Circuit, 83 VA. L. REV. 1717, 1719 (1997) (listing among a study's conclusions that "ideology significantly influences judicial decisionmaking on the D.C. Circuit").

266. Cf. Richard A. Posner, What Do Judges and Justices Maximize? (The Same Thing Everybody Else Does), 3 Sup. CT. ECON. REv. 1, 28-30 (1993) (analogizing judging to playing a game, and positing that judges appreciate playing the game by the rules).

267. See Richard L. Revesz, Congressional Influence on Judicial Behavior? An Empirical Examination of Challenges to Agency Action in the D.C. Circuit, 76 N.Y.U. L. REV. 1100, 1113 (2001) (reporting data consistent with the hypothesis that "in certain cases, judges constrain their ideological views in order to avoid a reputational cost"); Sidney A. Shapiro \& Richard E. Levy, Judicial Incentives and Indeterminacy in Substantive Review of Administrative Decisions, 44 DUKE L.J. 1051, 1054-58 (1995) (describing the tradeoff of craft and outcome as motivators for judicial behavior); Ronald A. Cass, Judging: Norms and Incentives of Retrospective Decision-Making, 75 B.U. L. REv. 941, 995 (1995) ("The principal incentive for judges is to adhere to professional norms - in order to maintain respect within the profession, to deflect criticism, and to conform to the judge's own expectations."). 
preferences because the standard directly calls for judges to weigh the policy arguments for the rule being reviewed.

\section{CONCLUSION}

In this Article I contend that, properly understood, judicial review under the reasoned decision-making standard precludes a court from considering political influence as a basis for an agency rule, but nonetheless allows an agency to consider such influence in rulemaking. I do so by identifying two fundamental attributes of such review, as courts have traditionally applied it, that have eluded scholarly focus and perhaps recognition altogether.

The first attribute is that agency reasons, which are what courts review, are justifications rather than motivations for agency action. From this attribute it follows that the irrelevance of politics for judicial review does not preclude politics as a legitimate agency consideration in rulemaking.

The second attribute is that reasoned decision-making requires an agency to make manifest the trade-offs generated by its rulemaking. Essentially, by forcing the agency to reveal the likely concrete implications of the rule, this attribute makes it more difficult for the president and Congress to "spin" the positions they stake out with respect to agency policy. It follows that, although judicial review is apolitical, it plays a role in political accountability by reducing barriers to public awareness of the trade-offs from rulemaking. It further follows that permitting an agency to credit politics as a justification for a rule would interfere with this role of judicial review by relieving the agency of its obligation to reveal the full implications of its rulemaking.

Having set out these attributes of review for reasoned decision-making, I have shown why as a matter of positive law they inhere to this standard of review as traditionally applied. I have further shown why they are desirable. Finally, I have shown how factoring political influence into judicial review would threaten the benefits provided by this standard of review. Thus the implications of this Article are profound both for the reasoned decision-making standard of review in general and for how politics fits within it. 